\title{
Sea Level Rise and Archipelagic States: A Preliminary Risk Assessment
}

\author{
David Freestone \\ George Washington University Law School, Washington DC, United States; \\ Co-Rapporteur, International Law Association Committee on International \\ Law and Sea Level Rise
}

Clive Schofield

WMU-Sasakawa Global Ocean Institute, World Maritime University,

Malmö, Sweden

\section{Introduction*}

There is now scant doubt in the scientific community that global mean sea levels are rising and that such sea level rise is accelerating. Indeed, the Intergovernmental Panel on Climate Change (IPCC) suggests that global mean sea level rise in the period 2006-2015 has been two and a half times the rate for the period 1901-1990, a rate of sea level rise stated with high confidence to be "unprecedented over the last century."1 Sea level rise, coupled with the increasing frequency and intensity of extreme weather events as a consequence of climate change, represent major threats to coasts through both erosion and inundation. Sea level rise also poses a threat to the extent of the maritime jurisdictional claims of coastal States as baselines, predominantly coincident with the low-water line along the coast, may "ambulate" and likely retreat landward,

* The authors are both members of the International Law Association Committee on International Law and Sea Level Rise. They would like to acknowledge and extend their sincere thanks to Professor Davor Vidas, the Committee Chair, and Mr. Kevin Baumert for their helpful reviews of, comments on and assistance with, an earlier version of the article. All faults of commission or omission are the authors' alone. The second author acknowledges research support through Australian Research Council Discovery Grant DP180101996, held jointly with colleagues Professor Stuart Kaye at the Australian National Centre for Ocean Resources and Security, University of Wollongong, Australia, and Professor Michael Petterson of Auckland University of Technology. The authors would also like to acknowledge the generous support provided by the Nippon Foundation for funding the cost of the open access fee.

1 Intergovernmental Panel on Climate Change (IPCC), Special Report on the Ocean and Cryosphere in a Changing Climate [IPCC Special Report], approved at its 51st Session, 20-23 September 2019, available online: <https://www.ipcc.ch/srocc/home/>. 
potentially leading to a corresponding shift in the outer limits of maritime claims if critical basepoints are impacted.

There has already been some commentary in the law of the sea literature on the issue, and the potential consequences, of ambulatory normal baselines in the context of sea level rise; however, this contribution is focused on the potential impacts of sea level rise on archipelagic States and their associated archipelagic baselines. Such baselines are linked to or anchored on normal baselines and so are potentially vulnerable to change as the normal baseline ambulates as coastal geography evolves over time. When such movement is exacerbated by sea level rise, the validity of certain archipelagic baselines and potentially even the archipelagic status of the State concerned may be brought in to question.

First, the article outlines the issues of potential impact of sea level rise on baseline limits and boundaries with particular reference to the work of the International Law Association (ILA) Committee on International Law and Sea Level Rise, its influential 2018 Report and the resulting ILA resolutions. ${ }^{2}$ It then highlights some of the relevant contemporary developments, including State practice on this issue, before looking in more detail at the potential impacts of sea level rise on archipelagos. It first examines the origins and rationale of the archipelagic concept before detailing the relevant provisions of the 1982 United Nations Convention on the Law of the Sea (UNCLOS) concerning archipelagic status and baselines. ${ }^{3} \mathrm{~A}$ preliminary assessment is then undertaken concerning the identification of potentially vulnerable archipelagic basepoints, notably small and especially low-elevation islands, reef features and low-tide elevations. Concluding thoughts and avenues for additional study are then provided.

\section{Sea Level Rise, Baselines, Maritime Limits and Boundaries}

The IPCC in its Fifth Assessment Report (AR5) revised the predictions in AR4, positing global mean relative sea level rise of up to just under one meter by

2 For example, the South Pacific Forum seems to have taken aboard its recommendations in their 2019 Funafuti, Tuvalu Communiqué; see n. 45 below.

31982 United Nations Convention on the Law of the Sea, UN Doc. A/CONF.62/122; 1833 United Nations Treaty Series 3 (1982); International Legal Materials 21 (1982): 1261; available online: <https://www.un.org/Depts/los >. 
$2100 .{ }^{4}$ According to its special reports issued since AR5, ${ }^{5}$ particularly the 2019 IPCC Special Report on the Ocean and the Cryosphere which uses the figure of 1.1 meters by 2100 , this may ultimately prove to be a conservative estimate. ${ }^{6}$ Moreover, AR5 suggests that sea level rise is likely to exhibit "a strong regional pattern, with some places experiencing significant deviations of local and regional sea level change from the global mean change." ${ }^{7}$ One meter or more of change in sea level may pose potentially serious, maybe even disastrous, threats to many coastal States, especially those with large, heavily populated and low-lying coastal areas, and to small, low-lying island States. Indeed, some studies have suggested that global sea level rise could exceed two meters by

4 The IPCC estimated mean sea level rise in the range of $0.5^{2-0.98} \mathrm{~m}$ by 2100 in keeping with a high representative concentration pathway for which radiative forcing reaches greater than 8.5 Watts per square meter $\left(\mathrm{W} \mathrm{m}^{-2}\right)$ (RCP 8.5). See especially J.A. Church et al., "Sea Level Change," in Climate Change 2013: The Physical Science Basis. Contribution of Working Group I to the Fifth Assessment Report of the Intergovernmental Panel on Climate Change (Cambridge University Press, 2013) [hereinafter "Sea Level Change," Contribution of WG I to AR5]; R.K. Pachauri and L.A. Meyer, eds., Climate Change 2014: Synthesis Report. Contribution of Working Groups I, II and III to the Fifth Assessment Report of the Intergovernmental Panel on Climate Change (Geneva: IPCC, 2015) [hereinafter AR5-Synthesis]; and "Summary for Policymakers," in Climate Change 2013: The Physical Science Basis. Contribution of Working Group I to the Fifth Assessment Report of the Intergovernmental Panel on Climate Change (Cambridge University Press, 2013) [hereinafter AR5-Summary for Policymakers].

5 These reports form part of the IPCC's cycle of work building towards the release of AR6 due for release in 2022. See, IPCC, "Sixth Assessment Report," available online: <https://www.ipcc .ch/assessment-report/ar6/>; O. Hoegh-Guldberg et al., "Impacts of $1.5{ }^{\circ} \mathrm{C}$ Global Warming on Natural and Human Systems," in Global Warming of $1.5^{\circ}$ C, An IPCC Special Report on the impacts of global warming of $1.5^{\circ} \mathrm{C}$ above pre-industrial levels and related global greenhouse gas emission pathways, in the context of strengthening the global response to the threat of climate change, sustainable development, and efforts to eradicate poverty, eds., V. Masson-Delmotte et al. (IPCC, 2018), available online: <http://www.ipcc.ch/report/sr15>, Ch. 3, 175-311, 206 [IPCC $1.5^{\circ} \mathrm{C}$ Special Report].

6 Under RCP 8.5, corresponding to a high pathway for which radiative forcing reaches greater than $8.5 \mathrm{~W} \mathrm{~m}^{-2}$ by 2100 and continues to rise for some amount of time. See, IPCC Special Report on the Ocean and Cryosphere in a Changing Climate, n. 1 above, Summary for Policymakers, p. 23.

7 Sea Level Change, Contribution of WG I to AR5, n. 4 above, p. 114O. In the 2019 Report of the UNGA Sixth Committee discussion of sea level rise (see below n. 49). New Zealand was reported as saying that some of its "Pacific island neighbours ... were experiencing sealevel rise nine times the global average." United Nations General Assembly (UNGA), Sixth Committee, 26th Meeting, 31 October 2019, UN Doc. A/C.6/74/SR.26 (2019), para. 88. 
$2100,{ }^{8}$ that the rate of sea level rise is highest in the tropics, ${ }^{9}$ and that low-lying tropical atolls may become uninhabitable by the end of the century. ${ }^{10}$

As the 2018 ILA Report acknowledged, in addition to the threat posed to low-lying coastal areas and their associated populations, as well as to coastal infrastructure from inundation by rising seas, there are also threats to the continued coastal State jurisdiction over the ocean spaces adjacent to such threatened territories. ${ }^{11}$ In particular, sea level rise has the potential to impact significantly the spatial extent of national claims to maritime jurisdiction. This could be particularly significant for small island developing countries, which, while often characterized as "small island," are nonetheless undoubtedly "large ocean" States with extensive maritime zone entitlements often measured from extremely low-lying basepoints, as permitted by UNCLOS. ${ }^{12}$ This is particularly true of many maritime zones that are measured from archipelagic baselines drawn in compliance with Part IV of UNCLOS.

Generally, the baseline from which States' maritime zones are measured is the "normal" baseline, determined in accordance with Article 5 of UNCLOS. ${ }^{13}$

8 See, for example, J.A. Hall et al., Regional Sea Level Scenarios for Coastal Risk Management: Managing the Uncertainty of Future Sea Level Change and Extreme Water Levels for Department of Defense Coastal Sites Worldwide (U.S. Department of Defense, Strategic Environmental Research and Development Program, 2016), p. 1.

9 For example, the Pacific Marine Climate Change Report Card 2018 suggested that the Pacific Islands experienced sea level rise of 3-6 mm per year in the period 1993-2017 "but with some notable differences between islands" with some islands in the Western Pacific (Solomon Islands, Papua New Guinea and Marshall Islands) subject to a higher rate of sea level rise (up to $6 \mathrm{~mm} /$ year) compared to islands further east (such as Samoa and Kiribati). See, Commonwealth Marine Economies Programme (смеP), Pacific Marine Climate Change Report Card 2018, eds., B. Townhill et al. (CMEP, 2018), available online: $<$ https://climateanalytics.org/media/cefas_pacific_islands_report_card_final_amended _spreads_low-res.pdf>.

10 See, C.D. Storlazzi et al., "Most atolls will be uninhabitable by the mid-21st century because of sea level rise exacerbating wave-driven flooding," Science Advances 4, no. 4 (2018): eaap9741, available online; <https://advances.sciencemag.org/content/4/4/eaap9741>.

11 See International Law Association (ILA), Final Report of the Committee on International Law and Sea Level Rise, presented at the 78th I LA Conference, Sydney, August 2018 (London: ILA, 2018) [hereinafter 2018 Report], available online: <http://www.ila-hq.org/index.php/ committees $>$. Also published as D. Vidas, D. Freestone and J. McAdam, International Law and Sea Level Rise. Report of the International Law Association Committee on International Law and Sea Level Rise (Leiden/Boston: Brill, 2019).

12 See, D. Freestone and C.H. Schofield, "Securing ocean spaces for the future? The initiative of the Pacific SIDS to develop regional practice concerning baselines and maritime zone limits," Ocean Yearbook 33 (2019): 58-59, p. 59.

Art. 5, UnClos, n. 3 above, Article 5 . 
From this baseline, States may measure their territorial sea, ${ }^{14}$ contiguous zone, ${ }^{15}$ exclusive economic zone $(\mathrm{EEz})^{16}$ and continental shelf. ${ }^{17}$ In other words, it is the points along the coast, known as basepoints, that control the definition of the outer limits to maritime zones. The 2018 Report highlighted that, if those "normal" baselines move inland as a consequence of sea level rise, so too will the outer limits of those maritime zones measured from such baselines. As a result of such shifting baselines and the consequential adjustments of the outer limits of maritime zones, waters previously under national jurisdiction could become part of the high seas. Moreover, changes to the baselines could impact upon maritime boundaries between adjacent or opposite States.

The ILA Committee had concentrated the first phase of its work on the more pressing short-term issue, namely that rising seas will be most likely to have their first impacts on small low-lying offshore islands and other similar geographical features which may have been used to generate maritime zones, ${ }^{18}$ or been used by the coastal State as basepoints for drawing straight baselines. ${ }^{19}$ However, the inundation of such islands and insular features may potentially have disproportional impacts on the ability of an archipelagic State to which they belong to maintain its compliance with the detailed requirements for archipelagic status set out by UNCLOS, possibly even compromising its ability to maintain its claim to archipelagic status. ${ }^{20}$

This current study seeks to examine at a preliminary level the potential impacts of sea level rise on the baseline systems of those 22 countries that currently claim archipelagic status and have established archipelagic baselines. In doing so it provides something of a case study of the resilience of the UNCLOS regime in relation to its ability, or otherwise, to withstand the impacts of climate change-induced sea level rise.

\footnotetext{
14 Id., Article 3.

15 Id., Article 33.

16 Id., Article 57.

17 Id., Article $76(1)$. Of course, defining the outer limit of the continental shelf is more complex as the continental shelf extends beyond a coastal State's territorial sea "throughout the natural prolongation of its land territory to the outer edge of the continental margin," and therefore for many coastal States it extends beyond 200 nautical miles from the baselines.

18 See generally the detailed provisions of Part II of UnCLos. For example, the low-water line of islands may be used to measure maritime zones (Art. 121(2)). The low-water line of low-tide elevations (LTE) may also be used to measure maritime zones if the LTE is situated "wholly or partly at a distance not exceeding the breadth of the territorial sea from the mainland or an island" (Art. 13(1)). All these features are susceptible to change.

19 As permitted by unCLOS, n. 3 above, Article 7.

20 Under Part IV of UNCLOS, discussed further below.
} 


\section{Building on the Work of the ILA}

The ILA Committee on International Law and Sea Level Rise was established following a recommendation of the $75^{\text {th }}$ ILA Conference, held in Sofia. ${ }^{21}$ During the first part of its mandate (2012-2018) this Committee studied the possible impacts of sea level rise and the implications under international law of the partial and complete inundation of State territory, or depopulation thereof, in particular of small island and low-lying States. The Committee also sought to develop proposals for the progressive development of international law in relation to the possible loss of all or of parts of State territory and maritime zones due to sea level rise, including the impacts on statehood, nationality, and human rights. ${ }^{22}$ After presenting an Interim Report in $2016,{ }^{23}$ the Committee presented its Final Report in August 2018 at the 78th ILA Conference. ${ }^{24}$ That report looked specifically at the short-term impacts of sea level rise on maritime zones and boundaries and also articulated some important principles for the protection of persons displaced in the context of sea level rise. ${ }^{25}$ It also looked at emerging State practice relating to the interpretation of UNCLOs. ${ }^{26}$

21 Recommendation 1/2012, 2012 ILA Report (ILA: London 2012).

22 ILA, Minutes of the Meeting of the Executive Council (London, 10 November 2012), p. 5. Documents from the ILA International Law and Sea Level Rise Committee are available online: <http://www.ila-hq.org/en/committees/index.cfm/cid/1043>. See also D. Vidas, D. Freestone and J. McAdam, "International law and sea level rise: The new ILA Committee," International Law Students' Association (ILSA) Journal of International and Comparative Law 21 (2015): 397-408. The authors were the chair and co-rapporteurs of the Committee, respectively.

23 ILA, Committee on International Law and Sea Level Rise, Johannesburg Conference: Interim Report 2016.

242018 Report, n. 11 above.

25 The Sydney Declaration of Principles for the Protection of Persons Displaced in the Context of Sea Level Rise. Resolution 6/2018, Committee on International Law and Sea Level Rise, 78 th Conference of the International Law Association, held in Sydney, Australia, 19-24 August 2018.

26 Note that Article 31(3) of the 1969 Vienna Convention on the Law of Treaties, International Legal Materials 8 (1969): 689, provides that in the interpretation of a treaty:

3. There shall be taken into account, together with the context:

(a) any subsequent agreement between the parties regarding the interpretation of the treaty or the application of its provisions;

(b) any subsequent practice in the application of the treaty which establishes the agreement of the parties regarding its interpretation (emphasis added).

Note also United Nations, Report of the International Law Commission: Sixty-eighth session (2 May-10 June and 4 July-12 August 2016) (UN Doc. A/71/10), p.121, Chapter vi: Subsequent agreements and subsequent practice in relation to the interpretation of treaties, Conclusion 4: Definition of subsequent agreement and subsequent practice: 
In relation to the impacts of sea level rise on maritime zones, the Committee's primary recommendation, which was also reflected in a plenary resolution of the ILA, ${ }^{27}$ was that States should accept that, once the baselines and the outer limits of the maritime zones of a coastal or an archipelagic State have been determined in accordance with the detailed requirements of UNCLOS, which also reflect customary international law, these baselines and limits should not be required to be readjusted should sea level change affect the geographical reality of the coastline. ${ }^{28}$

Following the 2018 Sydney Conference, the Sea Level Rise Committee was given a renewed four-year mandate to address the mid- and long-term impact issues remaining in its mandate. An organizing meeting for the second phase of its work (up to 2022) was held in Madrid in December 2019. ${ }^{29}$ One of the issues discussed then was the potentially disproportionate impact that sea level rise seems likely to have on archipelagic States. The proposal made by the 2018 Report specifically mentions archipelagic States as well as other coastal States. However, the Committee felt that the inundation of small, particularly low-lying, insular features through sea level rise might affect the validity of archipelagic baselines, and even the validity of archipelagic status claims themselves, given the relatively complex requirements of Part IV of UNCLOS. ${ }^{30}$ It thought these issues worthy of further study and review.

\section{Contemporary Developments}

\section{Regional State Practice}

The present authors have already written (including in this Yearbook) about the reactions of the Pacific Island States to the IPCC predictions on

2. 'subsequent practice' as an authentic means of interpretation under article 31, paragraph $3(\mathrm{~b})$, consists of conduct in the application of a treaty, after its conclusion, which establishes the agreement of the parties regarding the interpretation of the treaty.

3. Other 'subsequent practice' as a supplementary means of interpretation under article 32 consists of conduct by one or more parties in the application of the treaty, after its conclusion.

27 ILA Resolution 5/2018, available online: <https://www.ila-hq.org/images/ILA/Resolu tions/ILAResolution_5_2018_SeaLevelRise.pdf >.

28 Id.

29 See D. Vidas, "Madrid Meeting of the Committee on International Law and Sea Level Rise, December 2019," FIDE Foundation, available online: <https://www.fidefundacion .es/Madrid-Meeting-of-the-Committee-on-International-Law-and-Sea-Level-Rise -December-2019_an173.html>. UNCLOS, n. 3 above, Articles 46-54. 
sea level rise and emerging State practice in that region. ${ }^{31}$ Well in advance of the Paris Climate Conference, ${ }^{32}$ in 2010 the Pacific Island Forum adopted the Framework for a Pacific Oceanscape. The Framework includes a call for Pacific Island States and territories to deposit coordinates and charts delineating their maritime zones with the United Nations with a view to determining their maritime jurisdictions so that they "could not be challenged and reduced due to climate change and sea level rise." ${ }^{33}$ Moreover, in the immediate run up to Paris, the leaders of seven Polynesian States and territories issued, in July 2015, the Taputapuātea Declaration on Climate Change. ${ }^{34}$ This talks explicitly of their intent to "permanently establish the baselines in accordance with the [UNCLOS], without taking into account sea level rise."35

31 See particularly, C.H. Schofield and D. Freestone, "Islands awash amidst rising seas: Sea level rise and insular status under the Law of the Sea," in Proceedings of the 2018 Singapore Conference on Climate Change, International Journal of Marine and Coastal Law 34 (2019): 391-414; Freestone and Schofield (2019), n. 12 above; D. Freestone and C.H. Schofield, "Republic of the Marshall Islands: 2016 Maritime Zones Declaration Act: Drawing lines in the sea," International Journal of Marine and Coastal Law 31 (2016): $720-746$.

32 The Paris Climate Conference in December 2015 was the twenty-first session of the Conference of the Parties to the UN Framework Convention on Climate Change (UN FCCC COP 21) which finalized the Paris Agreement. United Nations Framework Convention on Climate Change (UNFCCC), adopted 9 May 1992, in force 21 March 1994, 1771 United Nations Treaty Series 107.

33 See C. Pratt and H. Govan, Our Sea of Islands, Our Livelihoods, Our Oceania. Framework for a Pacific Oceanscape: A Catalyst for Implementation of Ocean Policy (Pacific Islands Forum Secretariat, November 2010), pp. 57-58, available online: <http://www.forumsec.org/ wp-content/uploads/2018/o3/Framework-for-a-Pacific-Oceanscape-2010.pdf>.

34 The Taputapuātea Declaration on Climate Change states, inter alia, that "[T]he Polynesian Leaders Group call upon all States Parties to the UNFCC to ... With regard to the loss of territorial integrity: ... Accept that climate change and its adverse impacts are a threat to territorial integrity, security and sovereignty and in some cases to the very existence of some of our islands because of the submersion of existing land and the regression of our maritime heritage; Acknowledge, under the United Nations Convention on the Law of the Sea (UnClos), the importance of the Exclusive Economic Zones for Polynesian Island States and Territories whose area is calculated according to emerged lands and permanently establish the baselines in accordance with the UNCLOS, without taking into account sea level rise." It was signed by the leaders of French Polynesia, Niue, Cook Islands, Samoa, Tokelau, Tonga, and Tuvalu. Available online: $<\mathrm{https} / /$ www.samoagovt .ws/wp-content/uploads/2015/o7/The-Polynesian-P.A.C.T.pdf>.

35 The cultural significance of Taputapuātea adds to the importance of this Declaration. Its ancient marae temple complex is a UNEsco World Heritage Site. It is of outstanding universal value, inter alia, "as the ancestral homeland of Polynesian culture, Taputapuātea is of outstanding significance for people throughout the whole of Polynesia, for the way it symbolises their origins, connects them with ancestors and as an expression of their spirituality. These living ideas and knowledge are embedded in the landscapes and seascapes 
As part of a concerted action supported by the Pacific Islands Forum and its Secretariat, a number of small archipelagic States have also defined their baselines, delineated the outer limits of their maritime zones and delimited their maritime boundaries with a great deal of precision and detail. ${ }^{36}$ The legislation passed by the Republic of the Marshall Islands, for example, runs to more than 400 pages. ${ }^{37}$ Similar legislation, designating new archipelagic waters and designating the outer limits of the national EEzs, has also been passed by Kiribati ${ }^{38}$ and Tuvalu. ${ }^{39}$ The ostensible purpose of this legislation is to provide maritime jurisdictional clarity and certainty; however, the wider significance of such developments appears to be to anticipate that once established these "lines in the sea" defining baselines, limits and boundaries will not move in the future. ${ }^{40}$ As we have argued elsewhere, this can be seen as part of a regional move to secure the present spatial scope of States' maritime jurisdiction against the threat of ongoing sea level rise. This is not, however, to suggest that the views of these Pacific Ocean States are not shared by others, particularly small island developing States threatened by sea level rise in other parts of the global ocean.

This interpretation is supported by a series of declarations by the Pacific Island Leaders relating to the maintenance of existing maritime zones in the face of sea level rise. Following the approach of the 2015 Taputapuātea Declaration, in March 2018, eight Pacific Island leaders attending the second Leaders' Summit of the Parties to the Nauru Agreement (PNA) signed "The Delap Commitment on Securing Our Common Wealth of Oceans-reshaping the future to take control of the fisheries." ${ }^{n 1}$ The signatories agreed:

of Raiatea and particularly in the marae for the central roles that they once performed." See unEsco, "Taputapuātea," <https://whc.unesco.org/en/list/1529/>.

36 See further, Freestone and Schofield (2016), n. 31 above.

37 This and following section draws on Freestone and Schofield, id.

38 Republic of Kiribati, Baselines around the Archipelagos of Kiribati Regulations 2014 (2014), available online: <http://www.un.org/Depts/los/LEGISLATIONANDTREATIES/ PDFFILES/KIR_2014_archipel_baselines_regulations.pdf>, and Exclusive Economic Zone Outer Limit Regulations 2014 (2014), available online: <http://www.un.org/Depts/los/ LEGISLATIONANDTREATIES/PDFFILES/KIR_2014_eez_outer_limits_regulations.pdf > . Cited by S. Kaye, "The Law of the Sea Convention and sea level rise after the South China Sea Arbitration," International Law Studies 93 (2017): 423-445, p. 444.

39 Tuvalu, Declaration of Archipelagic Baselines 2012, LN No. 7 of 2012, available online: <http://www.un.org/Depts/los/LEGISLATIONANDTREATIES/PDFFILES/tuv_declara tion_archipelagic_baselines2012_1.pdf >.

$40 \quad$ Freestone and Schofield (2016), n. 31 above.

41 The Commitment was signed in Majuro in the Marshall Islands on 2 March 2018 by the heads of State or their representatives of the Federated States of Micronesia, Republic of Kiribati, Republic of the Marshall Islands, Republic of Nauru, Republic of Palau, 
To pursue legal recognition of the defined baselines established under the United Nations Convention on the Law of the Sea to remain in perpetuity irrespective of the impacts of sea level rise..$^{42}$

In September 2018, at the end of the forty-ninth Meeting of the South Pacific Forum Heads of State held in Nauru, ${ }^{43}$ the Forum issued the Boe Declaration on Regional Security, which reaffirms that "climate change presents the single greatest threat to the livelihoods, security and wellbeing of the peoples of the Pacific." ${ }^{44}$ Of even more significance is the communique issued a year later in August 2019 after the fiftieth meeting of the Pacific Islands Forum was held in Funafuti, Tuvalu. The communique-again adopted unanimously_included a number of provisions on maritime boundaries including the following:

26. Leaders committed to a collective effort, including to develop international law, with the aim of ensuring that once a Forum Member's maritime zones are delineated in accordance with the 1982 UN Convention on the Law of the Sea, that the Members maritime zones could not be challenged or reduced as a result of sea-level rise and climate change. ${ }^{45}$

This wording follows closely that of the ILA recommendation in its 2018 Report. This is not, it seems, a coincidence.

Independent State of Papua New Guinea, Solomon Islands and Tuvalu. Available online: $<$ https://pnatuna.com/sites/default/files/Delap\%2oCommitment_2nd\%20PNA\%2O Leaders\%2oSummit.pdf $>$.

42 Id., para. 8 (emphasis added).

43 The Forum includes all the Pacific Island small island developing States plus Australia and New Zealand.

44 See Pacific Islands Forum Secretariat, Forty-ninth Pacific Islands Forum, Yaren, Nauru, 3-6 September 2018, Forum Communiqué, Doc PIFS(18)10, Annex 1: Boe Declaration on Regional Security, Pacific Islands Forum Secretariat (5 September 2018), available online: $<$ https://uploads.guim.co.uk/2018/og/o5/1FINAL_49PIFLM_Communique_for_unofficial_release_rev.pdf >. The accompanying Pacific Islands Forum Communiqué, para. 26, recognizes specifically the "urgency and importance of securing the region's maritime boundaries" though framed around development and security as well as the Blue Pacific Continent visualization of the region."

45 Pacific Islands Forum Secretariat, Fiftieth Pacific Islands Forum, Funafuti, Tuvalu, 13-16 August 2019, Forum Communiqué, Doc PIF(19)14, available online: <https://www .forumsec.org/wp-content/uploads/2019/o8/5oth-Pacific-Islands-Forum-Communique . pdf $>$. 


\section{The International Law Commission}

In 2018, the UN International Law Commission (ILC) proposed the inclusion of the topic of 'Sea-level rise in relation to international law' in its long-term program of work. ${ }^{46}$ The proposal received support from nearly 120 UN Member States during the debate at the Sixth (Legal) Committee of the UN General Assembly, ${ }^{47}$ and was adopted in a 2018 General Assembly resolution. ${ }^{48}$ In turn, the ILC decided in May 2019 to include the topic in its active work program and to initially address it in an "open-ended Study Group."49 The ILC Study Group has structured the organization of its work in terms of three main issue-areas ('subtopics') of international law: "A) law of the sea, B) statehood, and C) protection of persons affected by sea level rise," following its syllabus prepared in $2018 . .^{50}$ The Study Group also considered a roadmap for its work and plans to initially address issues related to the law of the sea (subtopic A) in 2020, and issues related to statehood and the protection of persons affected by sea level rise (subtopics B and C) in 2021. ${ }^{51}$

The discussions held in October 2019 in the Sixth Committee of the UN General Assembly clearly demonstrated the increasing attention of many States to the international law implications of sea level rise, confirming also the timeliness of the inclusion of the theme of 'Sea level rise in relation to international law' as a new topic in the work program of the ILC. Many UN Members States commended the ILC for its proposed three-fold thematic structure of work, ${ }^{52}$ and-regarding the law of the sea in particular- several

46 United Nations, Report of the International Law Commission: Seventieth Session (3o April-1 June and 2 July-10 August 2018) (UN Doc. A/73/10), Annex B.

47 See P.G. Teles, "Sea-level rise in relation to international law: A new topic for the United Nations International Law Commission," in Global Challenges and the Law of the Sea, eds. M.C. Ribeiro et al. (Springer Nature, 2020), pp. 145-157.

48 UNGA Resolution 73/265 (UN Doc. A/RES/73/265) of 22 December 2018. See also, more recently, UNGA Resolution 74/186 (UN Doc. A/RES/74/186) of 18 December 2019.

49 United Nations, Report of the International Law Commission: Seventy-first Session (29 April-7 June and 8 July-9 August 2019) (UN Doc. A/74/10), paras. 9, 265.

$50 \quad$ Id., para. 269; UN Doc. A/73/10, n. 46 above, annex B, especially para. 19. For ILC reports on this matter, see generally UN Doc. A/74/10 (2019), Chs. III and x; UN Doc. A/73/10 (2018), Chs. III and XII, and Annex B.

$5^{1}$ UN Doc. A/74/10, n. 49 above, para. 267. It is planned that the conclusions of the ILC Study Group can be made available at the end of the current quinquennium (2017-2021) or more likely during the next (2021-2026), see Teles, n. 47 above, pp. $155^{-156 .}$

52 See, e.g., statements in the UN Sixth Committee debate (October-November 2019) by Peru (UN Doc. A/C.6/74/SR.27, para. 64); Fiji, on behalf of the Pacific small island developing States, including also Kiribati, Micronesia, Nauru, Palau, Papua New Guinea, Samoa, Solomon Islands, Tonga, Tuvalu, and Vanuatu (id., para. 79); Romania (UN Doc. A/C.6/74/ SR.28, paras. 14-15); Italy (id., para. 30); The Netherlands (id., para. 79); Argentina (UN 
States indicated their support for an approach to ensure certainty and stability under UNCLOS. ${ }^{53}$

The ILC plan of work is, in turn, organized around basically the same three issue-areas that the ILA Committee on International Law and Sea Level Rise defined at its first meeting in Washington, DC in April 2014. As stated in the record of that ILA Committee meeting: " $t$ the Chair ... identified three main issue areas to be dealt with by the Committee: the law of the sea, forced migration and human rights, and issues of statehood." ${ }^{24}$ The ILA Committee then divided its work thematically into two main stages. In the first phase (20142018) it focused on priority areas in a relatively shorter-term perspective, which involved two parallel streams of study: one on the law of the sea issues, regarding implications of sea level rise on maritime zones and boundaries; and the other on the migration and human rights issues. The results of that work are, as already mentioned above, contained in the Committee's 2018 Report and the two related ILA resolutions: Resolution 5/2018 (on the law of the sea) and Resolution 6/2018 (on the protection of persons displaced in the context of sea level rise), both adopted by the 78 th Biennial ILA Conference in Sydney, in August 2018, and published in 2019. ${ }^{55}$ In the second phase of its work (ongoing 2019-2022), the ILA Committee is focusing on the study of international law issues prompted by the mid- to longer-term predictions of sea level rise. The work of the Committee in this phase includes, in addition to the issues related to the law of the sea and territory, and to the rights of the affected population, the study of the statehood and international law personality questions, and other related issues of international law and international security.

\section{The South China Sea Arbitral Award}

Another important development to take into account in the sphere of international judicial and arbitral practice is the 2016 Award of the Annex VII Arbitral Tribunal on the Merits of the South China Sea Case between the Philippines

Doc. A/C.6/74/SR.29, para. 35); Ireland (id., para. 43); Thailand (id., para. 99); Portugal (id., para. 108); Mexico (id., para. 114); Japan (UN Doc. A/C.6/74/SR.3o, para. 34); Estonia (id., para. 61); Malaysia (id., para. 83); Philippines (UN Doc. A/C.6/74/SR.31, para. 9); Indonesia (id., para. 29); Bangladesh (id., para. 48).

53 UN Doc. A/CN.4/734 (12 February 2020), para. 44. Note that the ILC First Report is now available online: $<$ https://legal.un.org/docs/?symbol=A/CN.4/740>.

54 See ILA Committee on International Law and Sea Level Rise, Minutes of the Closed Session (I), Washington, DC, 9 April 2014, p. 2; see also Minutes of the Open Session, Washington, DC, 10 April 2014, pp. 1-2.

55 ILA, Report of the Seventy-eighth Conference, held in Sydney, 19-24 August 2018 (London: ILA, 2019), pp. 29-40 (resolutions) and pp. 866-915 (report). Published also separately in an edited version as Vidas, Freestone and McAdam eds., n. 11 above. 
and China. ${ }^{56}$ Among the issues to be decided was the status of several insular features under the law of the sea regime of islands codified in Article 121 of UNCLOS. ${ }^{57}$ The Tribunal devoted a great deal of attention to the provisions of Article 121(3), which provides that "[r] ocks which cannot sustain human habitation or economic life of their own shall have no exclusive economic zone or continental shelf." The Tribunal held that the term "rock" was not meant to apply only to features "composed of solid rock," ${ }^{58}$ otherwise "absurd results" would occur. ${ }^{59}$ There has been considerable discussion as to whether both of the requirements contained in Article 121(3), linked by the word "or", need to be satisfied for an insular formation to qualify as an island with full maritime zones. However, the Tribunal insisted that either of these legs can be satisfied-a disjunctive interpretation-but did observe that "economic activity is carried out by humans and that humans will rarely inhabit areas where no economic activity or livelihood is possible." ${ }^{60}$ Furthermore, the Tribunal ruled that the economic activity must not be purely exploitative; the feature must sustain an activity "of its own." 61

There is also great significance in the finding of the Tribunal that the assessment of the status of a feature is to be determined on the basis of its "natural capacity, that is, without external additions or modifications intended to increase its capacity" to support human habitation or an economic life of its own. ${ }^{62}$ The Tribunal's ruling also provided an important confirmation that reclamation activities, including the large-scale island-building and reclamation activities undertaken by China, and to a lesser extent by other States in the South China Sea, cannot transform a feature that was a rock within the meaning of Article 121(3) of UNCLOS in its natural condition into a fully entitled

56 South China Sea Arbitration (Philippines v. China), Award, PCA Case No 2013-19, ICGJ 495 (PCA 2016), 12th July 2016, Permanent Court of Arbitration [PCA].

57 This passage draws on D. Freestone, "Remarks" in Panel on "The regime of islands in the aftermath of the South China Sea Arbitration," Proceedings of the American Society of International Law (2019): 1-12; C.H. Schofield, "The regime of islands reframed: Developments in the definition of islands and their role in the delimitation of maritime boundaries under the international law of the sea," Brill Research Perspectives in the Law of the Sea (Leiden/Boston: Brill, 2021): 34-61.

$5^{8}$ South China Sea Arbitration, n. 56 above, para. 540.

59 Id., para. 481. Specifically, non-rocky features would generate EEZ and continental shelf rights whereas features composed of solid rock were denied such rights, regardless of whether they were capable of sustaining human habitation or an economic life of their own.

6 Id., para. 497 .

61 Id., para. 543 .

62 Id., para. 542. 
island. ${ }^{63}$ However, enhancing an existing fully entitled island to maintain its habitability does not compromise its ability to maintain the full suite of maritime zones-although it may, depending on the amount of work needed, be prohibitively expensive. ${ }^{64}$ The South China Sea case also confirmed that while a low-tide elevation cannot be converted through artificial intervention into a rock nor a rock into a fully entitled island within the meaning of Article 121 of UNCLOS, ${ }^{65}$ although a low-tide elevation (LTE) may also have an artificial island superimposed on top of it. ${ }^{66}$ However, it is a breach of international law, the Tribunal ruled, to destroy valuable coral reefs and other fragile ecosystems in the process - as China was also found to have done-especially where environmental impact assessments (EIAs) have not been undertaken, or, if they have, not been shared with neighboring States as required under the Convention. 67

Of course the South China Sea Tribunal's Award is only binding on the parties to the dispute. It is, however, the first detailed international judicial interpretation of Article 121(3) of UNCLOS and can be seen to disadvantage States that currently claim what the Tribunal termed the "windfall" gains of the marine resources of huge maritime zones from uninhabitable features. ${ }^{68} \mathrm{It}$ is also notable that the South China Sea Award did include substantial scope for flexibility. For example, it provides that in the case where a local community is only able to sustain itself by utilizing a range of maritime features, it would not "fail to inhabit a feature on the grounds that its habitation is not sustained by a single feature." ${ }^{69}$ Nor conversely would that group be "disabled from recognizing that such features possess an economic life of their own merely because not all the features are directly inhabited." ${ }^{70}$ Further, concerning the determination of "human habitation" under Article 121(3) of UNCLOS, the Tribunal found, without determining an arbitrary number, that the community involved

63 Id., para. 508.

64 Id., para. 511. Such an enhancement would, of course, need to be carried out in an environmentally acceptable way respecting the obligations to "protect and preserve the marine environment" in Article 192 and "rare and fragile ecosystems" as well as the "habitats of depleted, threatened or endangered species," including giant clams and as well as species of turtles, corals and fish, in Article 194(5) of UnCLOS. This can really only be done, said the Tribunal in a nod to the jurisprudence of the International Court of Justice (ICJ), after an appropriate environmental impact assessment as required by Article 206 of UNCLOS.

65 Id., para. 508.

66 Id., para. 1037.

67 Id., paras. 966, 989-991. See also UnCLOs, n. 3 above, Articles 205-206.

68 Id., para. 516.

69 Id., para. 544.

70 Id. 
"need not necessarily be large" and that, for example, "in remote atolls a few individuals or family groups could well suffice."71 The Tribunal also found that periodic rather than permanent habitation by nomadic people "could also constitute habitation" 72 as would use by populations that are sustaining themselves through a "network" or "constellation" of related maritime features. ${ }^{73}$

This farseeing interpretation of the entitlements of island communities, reached on the basis that the Tribunal was "conscious that remote island populations often make use of a number of islands, sometimes spread over significant distances, for sustenance and livelihoods," ${ }^{74}$ will likely be welcomed by many communities particularly in low-lying islands in the Pacific, and elsewhere, threatened by sea level changes.

The Tribunal also addressed the possibility that China's references to consideration of the Spratly Islands as a whole might signify an assertion on the part of China that the Spratly Islands should be enclosed within a system of archipelagic or straight baselines and therefore be considered as a single unit. ${ }^{75}$ The Tribunal specifically ruled out such possibilities. ${ }^{76}$ With respect to archipelagic baselines the Tribunal reasoned that their use "is strictly controlled" and "limited" by the Convention to archipelagic States in keeping with Article 46 of UNCLOS, namely, "a State constituted wholly by one or more archipelagos" and which may include other islands. ${ }^{77}$ As such, the Tribunal was explicit in stating that China is "constituted principally by territory on the mainland of Asia and cannot meet the definition of an archipelagic State." 78

\section{The Origins of Archipelagic Status}

The concept of archipelagic status is, in terms of its codification, essentially a creature of the Third United Nations Conference on the Law of the Sea, 1973-1982 (UNCLOS III). However, there had been a long history of discussion of the issue, stretching back even before the famous 1930 Hague Codification

\footnotetext{
71 Id., para. 542.

72 Id.

73 Id., para. 544 .

74 Id., para. 547.

75 Id., para. 573 .

76 Id., stating that it "cannot agree" with such options.

77 Id.

78 The Tribunal also ruled out the application of straight baselines to features, such as the Spratly Islands, not meeting the criteria for archipelagic baselines in order "to approximate the effect of archipelagic baselines" as this "would effectively render the conditions in Articles 7 and 47 meaningless.” Id., paras. 575-576.
} 
Conference, ${ }^{79}$ to a proposal in 1924 by Alvarez to the International Law Association, ${ }^{80}$ although no agreement on the issue was possible in 1930, principally because the width of the territorial sea was still in dispute. ${ }^{81} \mathrm{O}^{\prime}$ Connell takes the view that the 1951 Anglo-Norwegian Fisheries Case is also "relevant to a general principle of archipelagos" in that it placed emphasis upon the "economic interests peculiar to a region wherein sea and land intertwine in a complex fashion." ${ }^{82}$ In 1953, a Committee of Experts, consisting of geographers and hydrographers, meeting in The Hague, agreed that it was possible to draw straight baselines between islands less than five miles apart and treat them as a group and classify the enclosed waters as internal waters. This idea was reflected in a later amendment to the ILC report by J.P. François, ${ }^{83}$ which was the basis for the discussions at the First United Nations Conference on the Law of the Sea in 1958. However, the ILC ultimately decided not to include such a provision in its proposed draft text for the Conference, although it did express the hope that "if an international conference subsequently studies the proposed rules it will give attention to" the problems of groups of islands. ${ }^{84}$ Despite support at the Conference from a number of States, notably the Philippines and Yugoslavia, but also Indonesia and Denmark, the issue was

79 O'Connell records that: "The question of assimilating clusters of coastal reefs and cays for the purpose of determining sovereignty thereover arose on several occasions during the nineteenth century, notably the cases of the cays of Florida and Cuba, and the reef and banks of the Bahamas and Bermuda." D.P. O'Connell, The International Law of the Sea, ed., I.A. Shearer (Oxford, 1982), pp. 237-238. See also generally O'Connell's seminal paper: "Mid ocean archipelagos in international law," British Yearbook of International Law 45 (1971): 1-78.

8o See O'Connell (1971), n. 79 above, p. 5, citing Report of 33rd Conference of ILA (Stockholm, 1924), pp. 259 et seq. Alvarez was chair of the Committee on Neutrality. The work of the 1930 Hague Conference is cited in UN Doc. A/CONF. $13 / 18$ (1957), Part 1, section 1, UNCLOS I, I Off. Rec 289, 291 and in S. Nandan and S. Rosenne, eds., UN Convention on the Law of the Sea: A Commentary (Martinus Nijhoff, 1993) Vol. II, p. 423 [hereinafter Virginia Commentary].

81 Although there was some support at that point by Japan and Germany, O'Connell (1982), n. 79 above, p. 239.

82 Anglo-Norwegian Fisheries Case (UK v. Norway) [1951] ICJ Reports, 116; O'Connell, n. 79 above, p. 43 .

83 [1954] II International Law Commission Yearbook (YB ILC) 5.

84 O'Connell, n. 79 above, p. 245; United Nations, Report of the International Law Commission on the Work of its Eighth Session, 23 April-4 July 1956 (UN Doc. A/31/159), Article 10; Commentary II YB ILC 1956, para. 3, p. 270. Cited in Virginia Commentary, n. 8o above, Vol. II, pp. 399-400. 
excluded from the text of the subsequent $195^{8}$ Convention on the Territorial Sea and Contiguous Zone. ${ }^{85}$

Two years later at the Second UN Conference on the Law of the Sea (UNCLOS II), the Philippines and Indonesia made the case for the special position of mid-ocean archipelagos, but the matter was again deferred for further study. ${ }^{86}$ In fact, both the Philippines and Indonesia had already begun to take unilateral action to assert claims to the waters between the islands of their State; the Philippines by means of a note verbale to the UN Secretary-General in $1955^{87}$ and Indonesia in a communiqué of December 1957, also known as the Djuanda Declaration. ${ }^{88}$ The Djuanda Declaration is generally considered to be the seed of the Indonesian Archipelagic Outlook [Wawasan Nusantara] policy of $1973 \cdot{ }^{89}$ The Philippines claim, which was based on the co-ordinates describing the Philippines in the 1898 Treaty of Paris under which Spain ceded the islands to the United States, was met with protests from Australia, Japan, the United Kingdom, and the United States, and the Indonesian claim by protests from Australia, France, Japan, Netherlands, New Zealand, the United Kingdom and the United States. Despite these protests, after the failure of the $195^{8}$ Convention on the Territorial Sea to recognize this special status, both States then followed up with national legislation detailing their claims.

85 Four conventions emerged from the first United Nations Conference on the Law of the Sea, held in Geneva in 1958: Convention on the Territorial Sea and Contiguous Zone, adopted 29 April 1958, in force 10 September 1964) 516 United Nations Treaty Series 205; Convention on the Continental Shelf, adopted 29 April 1958, in force 10 June 1964, 499 United Nations Treaty Series 311; Convention on the High Seas, adopted 29 April 1958, in force 30 September 1962, 450 United Nations Treaty Series 11; and Convention on Fishing and Conservation of the Living Resources of the High Sea, adopted 29 April 1958, in force 20 March 1966, 559 United Nations Treaty Series 285.

86 Primarily because the Philippines based its case on an argument of historic waters, an issue that the UN General Assembly had already decided to study. UNCLOS II Official Records 51, cited O'Connell, n. 79 above, p. 246.

87 United Nations, Report of the International Law Commission Covering the Work of its Seventh Session, 2 May-8 July 1955 (UN Doc. A/2934), pp. 52-53, cited O'Connell, n. 79 above, p. 248

88 Issued by and named after Indonesian Prime Minister, Ir. H. Djuanda Kartawidjaja. According to O'Connell, n. 79 above, p. 249, this was first published in Hukum (Indonesian Law Journal) 1958 Nos 4-5, later in M.M. Whiteman, Digest of International Law (Washington, DC: State Dept., 1963-1973) Vol. 4, p. 284. See also A. Hamzah, "Laut, Teritorial dan Perairan Indonesia: Himpunan Ordonansi, Undang-Undang dan Peraturan Lainnya, Akademika Presindo" [Sea, Territory and Waters of Indonesia: Compilation of Ordinances, Acts, and other Regulations] (Jakarta, 1984), pp. 129-130.

89 Regarding the Wawasan Nusantara Department of Information, Republic of Indonesia, Decree of the People's Consultative Assembly of the Republic of Indonesia, no: III/MPR/1983 on the Guidelines of State Policy, Jakarta, Percetakan Negara, 1983. 
In 1960, Indonesian legislation declared that its territorial waters would extend seaward for 12 nautical miles (M) measured from baselines consisting of "straight lines connecting the outermost points on the low water mark of the outermost islands or part of such islands comprising Indonesian territory." This created a system of baselines around the Indonesian archipelago extending for over 8,00o M. This action was justified on the grounds that "since time immemorial" Indonesia has "constituted one entity" and that, in the interests of the territorial integrity of the Indonesian State, all the islands and waters lying between these Indonesian islands "should be regarded as a single unit." "Peaceful passage" of foreign vessels through these waters would be guaranteed so long as it was not harmful to the sovereignty of the Republic. The United States Department of State 1971 study of Indonesia's baseline claims indicated that at that time "[t]he United States Government has not recognized the socalled 'archipelago principle' as an accepted principle of international law." 91 Since that time the situation has changed, and from 1986 the United States recognized Indonesia's archipelagic claim on the condition that it was applied in full conformity with international law. ${ }^{92}$

In June 1961, the Philippines also passed legislation implementing its claim. ${ }^{93}$ As noted above, this too drew protests, notably from the United States. ${ }^{94}$ For example, the United States responded to the claim of the Philippines by stating that "there is no recognition in international law of any special regime for archipelagoes $[s i c] .{ }^{95}$ However, State practice relating to archipelagos

90 Indonesia, Act Concerning Indonesian Waters, 20 January 1960, Article 1. Reproduced in U.S. Department of State, The Geographer, "Straight Baselines: Indonesia," Limits in the Seas, No. 35 (Washington, DC: Bureau of Intelligence and Research, 1971).

91 The Geographer, "Straight Baselines: Indonesia" (1971), id., p. 9.

92 In 1989, the United States also indicated that, even though UNCLOS was not yet in force, the archipelagic provisions within it "reflect customary international law and codify the only rules by which a nation can now rightfully assert an archipelagic claim. See M. Pickering, S.J. Cummins and D.P. Stewart, eds., Digest of United States Practice in International Law 1989-1990 (Washington, DC: International Law Institute, Office of the Legal Adviser, U.S. Department of State, 2003), pp. 472-474, p. 472. See also J.A. Roach and R.W. Smith, United States Responses to Excessive Maritime Claims 3rd ed. (Leiden: Martinus Nijhoff, 2012), p. 204.

93 Republic Act, No. 3046. As amended in 1968 by Republic Act, No. 5446 to alter co-ordinates described incorrectly, per O'Connell, n. 79 above, p. 248.

94 U.S. Department of State, The Geographer, "Straight Baselines: The Philippines," Limits in the Seas, No. 33 (Washington, DC: Office of the Geographer, Bureau of Intelligence and Research, 22 March, 1973), p. 9. See also Roach and Smith, n. 92 above, pp. 211-214.

95 Such protests are routinely issued as part of the United States Freedom of Navigation Program, established in 1979, which is designed to counter what the United States deems to be excessive maritime claims. See Roach and Smith, n. 92 above, pp. 3-9. 
gradually grew, ${ }^{96}$ and by the time of UNCLOS III, which eventually produced the final text of the Convention, support for the establishment of a special regime to deal with archipelagos had become, according to Prescott and Schofield, "irresistible."

Like much of the carefully crafted "package deal" of the 1982 Convention, the regime for archipelagos in Part IV represents a compromise between the competing interests of archipelagic States and other States. For archipelagic States, apart from the symbolic significance of unity that archipelagic status represented, sovereignty over the waters between islands was an important consideration. Their key interests were security, access to and control over resources, and environmental protection. For other States, such interests included the preservation of traditional fishing rights, the continuation of rights to lay and maintain submarine pipelines and cables and, critically, freedom of navigation through and above the waters which now constituted archipelagic waters.

These competing interests were balanced in UNCLOS by providing archipelagic States with sovereignty over their archipelagic waters, thereby addressing their security, resource and environmental concerns. ${ }^{98}$ The security interests of archipelagic States were also addressed by specifying a limit on the distance from islands belonging to the archipelagic State that foreign vessels may navigate. Other State interests were, in turn, catered for through provisions relating to the protection of traditional fishing rights, submarine cables already laid (including their maintenance and replacement) by other States, and other legitimate activities, ${ }^{99}$ including, most importantly, navigational rights. ${ }^{100}$ Although the archipelagic State was given "sovereignty" over archipelagic waters, ${ }^{101}$ an important distinction was made between archipelagic waters

96 See H.W. Jayewardene, The Regime of Islands in International Law (Dordrecht: Martinus Nijhoff, 1990), pp. 113-142.

97 J.R.V. Prescott and C.H. Schofield, The Maritime Political Boundaries of the World (Leiden/ Boston: Martinus Nijhoff, 2005), p. 166.

98 Note this "sovereignty is exercised subject to [Part Iv]", UnCLOS, n. 3 above, Article 49(3).

99 Article 51(1) of UNCLOS, id., provides: "Without prejudice to Article 49, an archipelagic State shall respect existing agreements with other States and shall recognise traditional fishing rights and other legitimate activities of the immediately adjacent neighbouring States in certain areas falling within archipelagic waters."

100 Articles $5^{2}$ and 53 of UNCLOS, id., recognize the "right of innocent passage" and the "right of archipelagic sea lanes passage," with the latter including sea and air routes.

101 Article 49(1) of UNCLOS, id., provides explicitly that "the sovereignty of an archipelagic State extends to the waters enclosed by the archipelagic baselines drawn in accordance with Article 47." This is the case regardless of the depth of such waters or distance from the coast. Article 49(2) further provides that the archipelagic State has sovereignty not only over the archipelagic waters, but also the air space above them, as well as to their seabed and subsoil and all the resources contained within. 
and internal waters. ${ }^{102}$ Indeed, Article 50 envisages archipelagic States drawing closing lines for the delimitation of its internal waters, in accordance with the rules for rivers, bays, ports and permanent harbor works baseline. ${ }^{103}$ Rights of "innocent passage" which exist through any coastal States territorial sea were extended to the archipelagic waters enclosed within the baselines, and Article 53 introduced a new "non-suspendable" right of "archipelagic sea lanes passage," applicable to all foreign ships and aircraft in such sea lanes and air routes, analogous to the right of transit passage through international straits.

\section{Archipelagic Status under UNCLOS}

Article 46 of UNCLOS provides that:

For the purposes of this Convention:

(a) "archipelagic State" means a State constituted wholly by one or more archipelagos and may include other islands; and

(b) "archipelago" means a group of islands, including parts of islands, interconnecting waters and other natural features which are so closely interrelated that such islands, waters and other natural features form an intrinsic geographical, economic and political entity, or which historically have been regarded as such.

The most important political aspect of this definition is that these special rules may only be applied to island States and, in particular, groups of islands and the interconnecting water between them. ${ }^{104}$ This is apparently the result of the fact that at UNCLOS III it was felt necessary to limit the number of States admitted to the archipelagic bloc negotiation. Consequently, the negotiations with the major maritime States-which were primarily concerned with guaranteeing freedom of navigation-were conducted by four States only: Fiji, Indonesia, the Philippines and Mauritius. ${ }^{105}$ Ultimately, the definition excludes the archipelagos of mainland States from benefiting from the

\footnotetext{
102 UNCLOS, id., Article 5o.

103 Id.: "Within its archipelagic waters, the archipelagic State may draw closing lines for the delimitation of internal waters, in accordance with articles 9, 10 and 11."

104 It has been noted that the term 'other natural features' in Article 46(b) is somewhat obscure. However, this terminology can be taken to be a reference to drying reefs as mentioned in Article 47(1). See Prescott and Schofield, n. 97 above, pp. 167-168.

105 This was reportedly at the initiative of Philippines, Indonesia Fiji and Mauritius. UnCLOS III Official Records, Vol. III, p. 19o; O'Connell, n. 79 above, p. 257. The years that the other potential mid-ocean archipelagic States joined the UN are set out in Table 1.
} 
new regime. Although a number of mainland coastal States with sovereignty over groups of islands offshore argued during UNCLOS III that the special rules applicable to archipelagos should also be applicable to their offshore island possessions, these proposals were unsuccessful. ${ }^{106}$

The phrase "parts of islands" in Article 46(b) was included in order to accommodate the circumstances of archipelagic States such as Indonesia, which shares sovereignty over an island with another coastal State. In Indonesia's case the island of Borneo is shared with Brunei-Darussalam and Malaysia, the island of New Guinea is shared with Papua New Guinea and the island of Timor is shared with Timor-Leste. ${ }^{107}$

\section{Archipelagic Baselines}

The requirements for the drawing of archipelagic baselines are laid out in Article 47 of UNCLOS, reproduced in Appendix I of this article. These, and the other technical requirements in Part IV, were developed fairly early in the UNCLOS III process. At the 1975 Third Session, the Bahamas circulated among the other interested States its "18 Principles for Inclusion on the Archipelagic Articles" to summarize and help to expedite the negotiations among interested States. ${ }^{108}$

Article 47 lays down detailed and relatively strict and objective criteria for the drawing of archipelagic baselines. ${ }^{109}$ These can be summarized as follows:

106 See Jayewardene, n. 96 above, pp. 140-142. It is worth noting in this context that a number of mainland States with islands have sought to circumvent their inability to invoke the Part IV regime by instead defining straight baselines in relation to their offshore possessions. Such baselines are often reminiscent of archipelagic baselines. The baselines defined by Denmark around the Faroe Islands, by Ecuador around the Galapagos Islands and by Portugal concerning the Azores Islands provide examples of this type of State practice. See Prescott and Schofield, n. 97 above, p. 167. See also Roach and Smith, n. 92 above, pp. 108-110.

107 See Prescott and Schofield, n. 97 above, p. 169. Note that Indonesia formalized its control of West Papua through a controversial 1969 Act of Free Choice and that Indonesia occupied what was then Portuguese Timor from 1975 until the independence of Timor-Leste in 2002.

108 Reproduced in Virginia Commentary, n. 8o above, Vol. II, pp. 405-406. At the end of the Conference a number of other delegations indicated they would claim this status: the Bahamas, Cape Verde, Fiji, Netherlands Antilles, Papua New Guinea, the Philippines, Solomon Islands and São Tomé and Príncipe. Id., p. 403.

109 See ILA, Sydney Conference: Report of the Baselines under the International Law of the Sea Committee: Final Report (2018). Also see C.G. Lathrop, J.A. Roach and D.R. Rothwell, eds., "Baselines under the international law of the sea: Reports of the International 
1. that archipelagic States "may draw straight archipelagic baselines joining the outermost points of the outermost islands and drying reefs of the archipelago" provided that the "main islands" of the archipelagic State are included within the archipelagic baseline system;110

2. that the ratio of water to land within the baselines must be between 1:1 and 9:1;11

3. that the length of any single baseline segment must not exceed $125 \mathrm{M} ; 112$

4. that no more than three per cent of the total number of baseline segments enclosing an archipelago may exceed $100 \mathrm{M} ;{ }^{113}$ and,

5. that such baselines "shall not depart to any appreciable extent from the general configuration of the archipelago."114

Of particular note for present purposes is the stipulation in Article 47(1) that, in defining the State's system of straight baselines, these baselines should

Law Association Committee on Baselines under the International Law of the Sea," Brill Research Perspectives on the Law of the Sea 2, no. 1-2 (2019): 1-177, pp. 98-112.

110 UNCLOS, n. 3 above, Article 47(1). This represents the critical test of the validity of a system of archipelagic baselines. The intent of this provision appears to be to exclude both coastal States dominated by a few large islands and those whose islands are particularly dispersed, such as the United Kingdom and Kiribati respectively. For a discussion of how the 1 to 1 and 1 to 9 ratios were arrived at, see Jayewardene, n. 96 above, p. 145. Article 47(7) provides clarification as to what may be reasonably regarded as water and land in order to aid in the computation of the crucial water to land ratio, providing that for this purpose "land areas may include waters lying within the fringing reefs of islands and atolls, including that part of a steep-sided oceanic plateau which is enclosed or nearly enclosed by a chain of limestone islands and drying reefs lying on the perimeter of the plateau."

111 UNCLOS, n. 3 above, Article 47(1).

112 Id., Article 47(2).

113 Id. The requirement that no more than three percent of baseline segments may exceed 100 $\mathrm{M}$ in length appears restrictive. However, this is illusory because it is the coastal State that constructs the archipelagic baseline system and as there is no restriction on the number of baselines that an archipelagic State might draw, it is usually possible to adjust the baseline system to overcome the no more than three percent of baseline segments exceeding 100 nautical miles in length restriction and thus conform to the UNCLOS requirements. See United Nations Division for Ocean Affairs and the Law of the Sea, Handbook on the Delimitation of Maritime Boundaries (New York: United Nations, 200o), p. 8.

114 It can be noted that although these rules appear to be reasonably strict, Prescott was of the view that " $[\mathrm{t}] \mathrm{hree}$ of the five tests are incapable of consistent objective interpretation." See J.R.V. Prescott, "Straight and archipelagic baselines," in G.H. Blake, ed., Maritime Boundaries and Ocean Resources (Beckenham: Croom Helm, 1987), chap. 3, p. 46. See also Lathrop et al., n. 109 above, p. 101. For a more detailed analysis of navigational issues related to archipelagic baselines and archipelagic waters see M.B Tsamenyi, C.H. Schofield and B. Milligan, "Navigation through archipelagos: Current State practice," in Freedom of the Seas, Passage Rights and the 1982 Law of the Sea Convention, eds., M.H. Nordquist, T.B. Koh and J.N. Moore (The Hague: Martinus Nijhoff, 2008), pp. 413-454. 
link "the outermost points of the outermost islands and drying reefs of the archipelago." Fundamentally, a system of archipelagic baselines comprises a series of basepoints located on the normal baseline along the coasts of a number of insular features. Consequently, archipelagic baselines are reliant on potentially ambulatory low-water lines along the coast in order to ensure that the baseline system is "closed".115 The insular features involved may include low-tide elevations both falling within the breadth of the territorial sea measured from an above high-tide coast and low-tide elevations lying beyond that distance so long as such features have a lighthouse or similar installation located on them. ${ }^{116}$ While this may mean that the maximum amount of area may be enclosed, it also arguably encourages the use of features that are inherently peripheral and also potentially insubstantial and therefore potentially vulnerable to sea level rise.

Some island States composed of small and dispersed groups of islands have found it challenging to define broad areas of archipelagic waters, primarily because of the ratio test. For example, the Federated States of Micronesia (FSM), which comprises over 600 islands, is clearly an island State and potential archipelagic State in keeping with the terms of Article 46. ${ }^{117}$ However, these islands are predominantly small such that FSM has a total land area of just over $700 \mathrm{~km}^{2}$ with over 5 o percent of this area provided by the largest island, Pohnpei, and widely scattered spanning around 2,900 km from east to west, ${ }^{118}$ and generating an EEZ estimated at almost 3 million $\mathrm{km}^{2} .{ }^{119}$ Consequently, FSM has as yet been unable to define baselines that meet the ratio requirements of Article 47(1). Jayewardene comments that it "would require a water to

115 See United Nations, Baselines: An Examination of the Relevant Provisions of the United Nations Convention on the Law of the Sea (New York: UN Office for Ocean Affairs and the Law of the Sea, 1989), p. 23.

116 Id., p. 36. The United Nations Group of Technical Experts on Baselines indicated that this rule combines the provisions of Articles 13(1) and 7(4) of UNCLOS and "so differs from the rules for applying the method of straight baselines."

117 FSM will qualify as an archipelagic State if its islands and interconnected waters form one or more archipelagos which form "an intrinsic geographical, economic and political entity or have historically been regarded as such" in accordance with Article 46(2) of UNCLOS.

118 Pohnpei has an area of $371.6 \mathrm{~km}^{2}$, which is 53 percent of FSM's total land area of 702 $\mathrm{km}^{2}$. See B.E. Sawe, "Largest islands in the Federated States of Micronesia," World Atlas (25 April 2017), available online: <https://www.worldatlas.com/articles/largest-islands -in-the-federated-states-of-micronesia.html\#: :text=Pohnpei,miles\%2o(371.6\%20 square $\% 20 \mathrm{~km}$ ) $>$.

119 Food and Agriculture Organization of the United Nations (FAO), "Fishery and Aquaculture Country Profiles: The Federated States of Micronesia” (March 2018), available online: $<$ http://www.fao.org/fishery/facp/FSM/en $>$. 
land ratio of 40 or 50 to 1 if an enclosure is to be made."120 However, in recent years analogously dispersed small island States, such as Kiribati have managed to define archipelagic baselines albeit of a limited nature and encompassing relatively restricted areas of archipelagic waters within them (see below). ${ }^{121}$

The potential loss of features that constitute key basepoints or turning points in the archipelagic baselines system may mean that the remaining basepoints are further apart than the Convention permits or it may mean that the resulting water-to-land ratio proportions no longer meet the necessary ratio requirements. ${ }^{122}$ Leaving aside for the present the impact such changes might have on the State's maritime zone claims, such changes might actually compromise the State's ability to maintain its claim to archipelagic status for the purposes of Part IV of UnClos. Although the group of islands would still remain an archipelago geographically and politically, it could lose all the advantages that UNCLOS confers.

It is worth looking at the water-to-land ratio issue in a little more detail. A ratio test was first proposed in 1973 by the United Kingdom as part of a series of objective criteria for applying straight baselines to archipelagic States; the figure it proposed was a $5: 1$ maximum water-to-land ratio. ${ }^{123}$ At the third session of UNCLOS III in 1975, the Bahamas proposed "Principles" contained a formula of between 1:1 and 9:1. ${ }^{124}$ This was reportedly "intended to embrace the claims of all the potential archipelagic States identified by the participants at the Conference."125

The result of the adoption of these ratios is that there are a number of large island States, at one end of the scale, that are disqualified from claiming

120 See Jayewardene, n. 96 above, p. 146.

121 See, for example, U.S. Department of State, "Republic of Kiribati: Archipelagic and other Maritime Claims and Boundaries," Limits in the Seas, No. 146 (Washington, DC: Office of Ocean and Polar Affairs, Bureau of Oceans and International Environmental and Scientific Affairs, 5 March 2020).

122 Article 47(1): "An archipelagic State may draw straight archipelagic baselines joining the outermost points of the outermost islands and drying reefs of the archipelago provided that within such baselines are included the main islands and an area in which the ratio of the area of the water to the area of the land, including atolls, is between 1 to 1 and 9 to 1." Article 47(2): "The length of such baselines shall not exceed 100 nautical miles, except that up to 3 per cent of the total number of baselines enclosing any archipelago may exceed that length, up to a maximum length of 125 nautical miles."

123 Committee on Peaceful Uses of the Sea-Bed and the Ocean Floor beyond the Limits of National Jurisdiction, "United Kingdom: Draft Article on the Rights and Duties of Archipelagic States (2 August 1973), UN Doc. A/AC.138/SC II/L.44, draft article, paras. 1, 2, 3 and 11, reproduced in III SBC Report 1974, at p. 99(UK).

124 UNCLOS, n. 3 above, Article 47(1).

125 Virginia Commentary, n. 8 o above, Vol. II, p. 423. 
archipelagic status because they have too much land, such as the United Kingdom and Japan. At the other end of the scale are the small island States that struggle to find enough land to meet even the one-to-one ratio, even though internal waters such as those inside a lagoon may be counted as land.

In order to seek to meet this considerable challenge, five States, Kiribati, the Marshall Islands, Mauritius, Seychelles and Solomon Islands, have drawn a series of archipelagic baselines around a number of separate groups of islands. The special case under Article 47(7) of the Seychelles is discussed below. ${ }^{126}$ Among these multi-archipelago States, the Marshall Islands and the Solomon Islands appear to have taken the view that their archipelagic claim meets the requirement of Article 47(1) of UNCLOS if the cumulative ratio of water to land in all their archipelagos is within the limits, even if the ratio within an individual archipelago might exceed the 9:1 test. ${ }^{127}$

It is clear that the UNCLOS III negotiators envisaged a single island State establishing more than one system of baselines. Article 46(1) defines an archipelagic State as one comprised "wholly by one or more archipelagos" (emphasis added). As the Virginia Commentary suggests, "as long as the objective criteria of article 47 are met, there appears to be no objection to the archipelagic State's inclusion of these archipelagos with archipelagic baseline envelopes." ${ }^{128}$ One of those objective criteria is the ratio of water to land.

In fact, Article 47(1) specifically permits baselines to be drawn joining the outermost points of the outermost islands and drying reefs of an archipelago (not the archipelagic State) "provided that within such baselines are included the main islands and an area in which the ratio of the area of the water to the area of the land, including atolls, is between 1 to 1 and 9 to 1" (emphasis added). A plain reading of this provision is that both requirements are necessary for each archipelago. However, there seems to be little record of the discussions which led to the requirement that each archipelago meet this criterion. It can be noted that the United States, in its systematic analysis of the archipelagic claims, has objected to this "cumulative ratio" practice where

126 See below text at n. 183 .

127 In the Solomon Islands the Ontong Java group seems problematic. If the atoll lagoon waters of the Ontong Java archipelago are considered as part of land area, then the waterto-land ratio for that group is $0.29: 1$ thus failing the 1:1 water-to-land requirement, though the cumulative ratio is 4.03:1. If the lagoon areas are counted as part of water area, the water-to-land ratio is 29.92:1, exceeding the 9:1 ratio limit under Article 47(1) of UNCLOS. See U.S. Department of State, "Solomon Islands: Archipelagic and other Maritime Claims and Boundaries," Limits in the Seas, No. 136 (Washington, DC: Office of Ocean and Polar Affairs, Bureau of Oceans and International Environmental and Scientific Affairs, 28 March 2014), p. 3 [hereinafter Solomon Islands Archipelagic Claims].

Virginia Commentary, n. 80 above, Vol. II, p. 430. 
individual systems of archipelagic baselines exceed the ratio thresholds, even if the cumulative total ratio overall is within the 9:1. ${ }^{129}$

Another provision of Article 47 that is worth flagging is paragraph 7 that reads:

For the purpose of computing the ratio of water to land under paragraphl, land areas may include waters lying within the fringing reefs of islands and atolls, including that part of a steep-sided oceanic plateau which is enclosed or nearly enclosed by a chain of limestone islands and drying reefs lying on the perimeter of the plateau. ${ }^{130}$

This provision is adopted verbatim from the third of the Principles that the Bahamas put forward to UNCLOS III in $1975 .{ }^{131}$ This seems to have been designed to accommodate the situation of the Bahamas themselves. Seychelles, on the other hand, appears to have relied on this provision in relation to three of the four island groups that make up its archipelagic claim: Group 1 (Mahé and other islands), Group 2 (Farquhar and Providence Atolls) and Group 3 (Cosmoledo Atoll and Astove Island), which lie above submerged banks. ${ }^{132}$ Without counting the submerged banks as land the ratios would be, according to the U.S. State Department, respectively Group 1: 10.58 to 1; Group 2: 239.93 to 1; and Group 344.5 to 1 and therefore exceed the 9:1 ratio requirement under Article $47(1)$ of UnCLOS. ${ }^{133}$ The State Department analysis went on to suggest that if the underwater features on which Seychelles Groups 2 and 3 are located were considered to be "part of a steep-sided oceanic plateau which is enclosed or nearly enclosed by a chain of limestone islands and drying reefs lying on the perimeter of the plateau" consistent with Article 47(7) of UNCLOS, then these

129 See further below at n. 183 .

130 Emphasis added.

131 See n. 108 above.

132 The Group 4 Aldabra Atoll and Assomption Island water-to-land area ratio is 5.15 to 1 . See Seychelles, Maritime Zones (Baselines) Order, 2008 (S.I. 88 of 2008), as amended by Maritime Zones (Baselines) Amendment Regulations, 2009 (S.I. 35 of 2009), Law of the Sea Bulletin, No. 70 (2009): 16-25; U.S. Department of State, "Seychelles: Archipelagic and Other Maritime Claims and Boundaries," Limits in the Seas, No. 132 (Washington, DC: Office of Ocean and Polar Affairs, Bureau of Oceans and International Environmental and Scientific Affairs, 14 February 2014), p. 3 and 10-15 [hereinafter Seychelles Archipelagic Claims].

133 Seychelles Archipelagic Claims, n. 132 above, pp. 2-3. 
groups "could meet the water-to-land area ratio criterion" under Article 47(1) of UNCLOS. ${ }^{134}$

Coastal States do of course have the option to undertake physical measures to maintain their existing baselines. Article 47(4) provides that an archipelagic baseline shall not be drawn to and from low-tide elevations, "unless lighthouses or similar installations which are permanently above sea level have been built on them." Existing features which are above high tide but threatened by sea level rise may also be artificially enhanced or built on to keep them above high tide so they remain valid basepoints. While this may be appropriate in some instances, the sort of physical intervention required to artificially maintain critical basepoints and maintain them over time is inevitably an expensive endeavor and is therefore likely to be a challenging one for some threatened archipelagic, yet also small-island developing, States. ${ }^{135}$ Here it must be noted that the legal status of features that cannot be altered through human intervention ${ }^{136}$ is distinct from building work designed to maintain the elevation above high tide of an existing fully entitled island—work that would

134 Id. The State Department report took exception to Seychelles Group 1, however, as "it does not appear as though Seychelles Bank is 'enclosed or nearly enclosed by a chain of limestone islands and drying reefs lying on the perimeter of the plateau' as described in Article 47.7 " of UNCLOS. Here it is worth noting that Seychelles' own calculations differ considerably from those of the U.S. State Department, yielding water-to-land ratios of 1:8.972 (Group 1), 1:4.94 (Group 2), 1:2.37 (Group 3) and 1:1.58 (Group 4) respectively, thus suggesting that the Seychelles claims meet the ratio requirements under Article 47(1) of UnCLOS. See R.F. Chang Tave and F. Coeur de Lion, "Delimitation of Seychelles Maritime Spaces," presentation, March 2019.

135 For an extreme example, Japan is reported to have spent over US\$200 million in the late 198 os on the construction of sea defenses for its southernmost insular feature, Okinotorishima, from which it claims EEZ and continental shelf rights. Further, in 2016, it was reported that Japan was set to spend a further $¥_{13}$ billion (over US\$10o million) to replace the existing elevated platform at Okinotorishima and to build additional facilities, including a lighthouse and pier. See J. Brown et al., Case Studies in Oceanography and Marine Affairs (Oxford: Pergamon Press, 1991), pp. 84-85; A.L. Silverstein, "Okinotorishima: Artificial preservation of a speck of sovereignty," Brooklyn Journal of International Law 16, no. 2 (1990): 409-431, p. 410; N. Jenkins, "Japan is spending $\$ 107$ million to rebuild a tiny Pacific Island," Time (2 February 2016), available online: <https://time.com/4205570/ okinotorishima-japan-maritime-claims/>; J. Ryall, "Japan spends millions building structures on uninhabited rocks 1,740 km from Tokyo to mark its territory," South China Morning Post (2 February 2016), available online: <https://www.scmp.com/news/asia/east-asia/ article/1908706/japan-spends-millions-building-structures-uninhabited-rocks-1740>.

${ }_{13} 6$ For example, the Arbitral Tribunal in the South China Sea case observed a low-tide elevation "cannot be legally transformed into an island through human efforts" and similarly that "a rock cannot be transformed into a fully entitled island through land reclamation." See South China Sea Arbitration, n. 56 above, para. 508. 
serve to maintain human habitability and related economic life and thus the island's full maritime entitlements. ${ }^{137}$

\section{The Use of Vulnerable Features in Archipelagic State Practice}

As discussed above, the provision of Article 47(1) that archipelagic States "may draw straight archipelagic baselines joining the outermost points of the outermost islands and drying reefs of the archipelago" potentially enables such States to employ peripheral features that may be vulnerable to sea level rise. Examples of such features include:

1. Small, low-elevation islands, especially those composed of soft sediments that may be readily eroded as a consequence of sea level rise as well as by the impacts of more frequent and intense extreme weather events, which may become more intense as a result of climate change induced weather changes;

2. Reefs-several archipelagic States are partly or wholly composed of coral reefs and such features have often been incorporated into archipelagic baseline systems;

3. Low-tide elevations - a limited number of States have used LTEs, that is, features which are uncovered at low tide but covered at high tide, as part of their claimed baselines.

A total of twenty-two States have been identified as claiming archipelagic status under UNCLOS and have defined systems of archipelagic baselines. Baumert and Melchior in their 2015 study of twenty of these claims reviewed their compliance with the provisions of Part IV. ${ }^{138}$ The following section will look at the extent to which each of these three types of features are utilized in practice in order to assess the degree of the risk involved.

\section{Small, Low Elevation Islands}

A preliminary survey of the claims of archipelagic States indicates that a number of archipelagic baselines systems have used small islands and potentially vulnerable island features as basepoints. This is in line with the provisions of Article $47(1)$ that "the outermost islands ... of the archipelago" may be joined

137 Id., para. 511

138 They suggest that the archipelagic status provisions of UNCLOS now represent customary international law. See K. Baumert and B. Melchior, "The practice of archipelagic States: A study of studies." Ocean Development and International Law 46 (2015): 6o-8o, p. 61. The authors are from the U.S. State Department. It is noted that Baumert and Melchior did not include the Marshall Islands and Kiribati in their survey. 
to form archipelagic baselines. Almost by definition some of these outermost features will be vulnerable to sea level rise.

In making this survey, the present authors have recognized that more contemporary sources are generally to be preferred for this information on the basis that they are more likely to reflect the current reality of the coast and in the present context, particular insular features. ${ }^{139}$ However, it can also be noted that the transition from paper to electronic charting has meant that older editions of traditional sources of hydrographic information, such as sailing directions or pilots, tend to be richer sources of observations than more recent ones, for instance often including heights of features above high tide level which more recent sources lack, and are therefore worthy of consideration. This is vividly demonstrated by the information gathered from these sources with respect to certain potentially vulnerable archipelagic basepoints. ${ }^{140}$

For example, the features securing the southern extent of Jamaica's archipelagic claim, Blower Rock (Point 27 in Jamaica's archipelagic baseline system), Southwest Rock (point 28) and to a lesser extent Morant Cays (Points 22-26), appear to be vulnerable to inundation with heights recorded in 1971 of $0.6 \mathrm{~m}$ (2 feet), $1 \mathrm{~m}$ (3 feet) and between 2 and $5 \mathrm{~m}$ respectively (see Figure 1). ${ }^{141}$

Given that Jamaica has a water-to-land ratio calculated at 2:1, were all of Jamaica's small southern insular features to be inundated as a consequence of sea level rise, Jamaica would no longer be able to define archipelagic baselines that met the minimum 1:1 water-to-land ratio required under Article 47(1) of UNCLOS. ${ }^{142}$ If, alternatively, Blower Rock and Southwest Rock were eliminated as a consequence of sea level rise, but Morant Cays remained above high tide, Jamaica would be forced to use basepoints located nearer to the mainland. In this context it can be observed that both Blower Rock and Southwest Rock

139 For example, in its examination of the feature the ICJ in the Nicaragua v. Colombia case, did not regard "surveys conducted many years (in some cases many decades) before the present proceedings" to be "relevant" to the issue of determining whether any naturally formed areas of land above high-tide existed on the feature Quitasueño and instead preferred to rely on "contemporary evidence" as this was based on "actual observations of conditions" combined with their "scientific evaluation." See Territorial and Maritime Dispute (Nicaragua v. Colombia), Judgment, [2012] ICJ Reports 50, para. 35.

140 The South China Sea Tribunal commented similarly "[a]s with published nautical charts, satellite navigation has also caused the more-recent editions of the pilots to become less descriptive of the features on reefs and correspondingly less useful to the particular determination presented to the Tribunal." See South China Sea Arbitration, n. 56 above, para. 331.

141 Hydrographer of the Navy, West Indies Pilot, Volume I, NP70, 1st ed. (Taunton: Hydrographic Department, 1971), p. 25 o.

142 See U.S. Department of State, "Jamaica's Maritime Claims and Boundaries," Limits in the Seas, no. 125 (Washington, DC: Office of Ocean and Polar Affairs, Bureau of Oceans and International Environmental and Scientific Affairs, 5 February 2004), p. 4. 


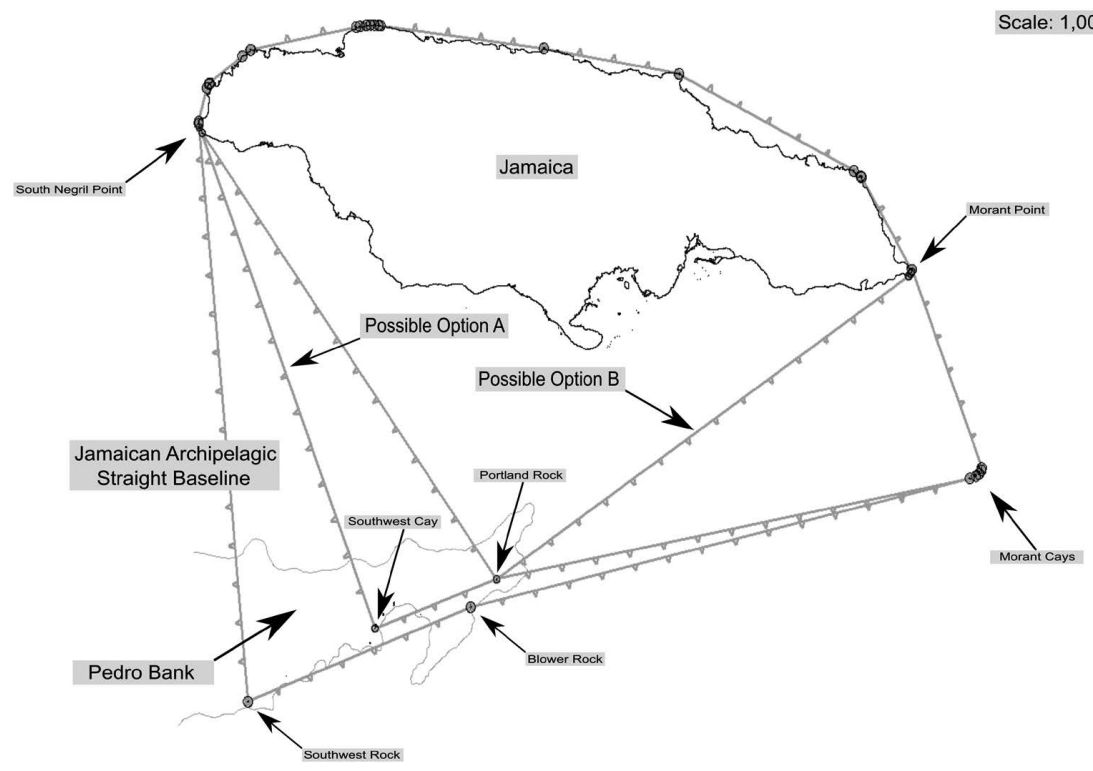

FIGURE 1 Jamaica's archipelagic baselines and potential fall-back positions

The authors are most grateful to Robert Van de Poll, Global Director Law of the Sea, Fugro, for his assistance in creating this graphic and assistance in area calculations. These calculations relied on mapping through Fugro 4DSSM which is a customized proprietary qualitative data visualization technique that is designed to make information in a satellite image (or a series of images for time-based analysis) more visually intuitive to a trained human observer. It is used to assist in interpreting seabed forms (seafloor morphology) where absolute knowledge of bathymetry is not known. As such it is a preliminary site investigation mapping tool

are located on a large predominantly submerged feature called Pedro Bank and there are a number of more landward features to fall back to. ${ }^{143}$ For example, were Jamaica to use Portland Rock and the largest feature in the Pedro Cays, notably Southwest Cay (Bird Cay), as basepoints instead of Blower Rock and Southwest Rock, Jamaica would lose around 3,789 km² of archipelagic waters but would still have a system of archipelagic baselines compliant

143 Pedro Bank is a large, predominantly underwater bank approximately $70 \mathrm{~km}$ along its east-west axis and $43 \mathrm{~km}$ broad at its eastern end located around $37 \mathrm{M}$ southwest of the Jamaican mainland. See United Nations Environment Programme World Conservation Monitoring Centre (UneP-WCMC), "Pedro Bank and Cays Management Area" (1988), available online: <https://web.archive.org/web/20070223063734/http://sea.unep-wcmc .org/sites/pa/o524q.htm>. 
with the objective tests of Article 47 of UNCLOS with a water-to-land ratio of approximately 1.6:1 (see Option A on Figure 1).

Here it can be noted that Portland Rock is, as its name implies, a rocky limestone feature rather than a coral cay and, while small in area, is of considerably higher elevation than Jamaica's other southern features being reported to be 10.5 m high. ${ }^{144}$ Pedro Cays are relatively substantial, though predominantly lowlying $(3 \mathrm{~m})$ features comprising from north to south, North-East Cay (7.5 ha, $3 \mathrm{~m}$ ), Middle Cay (4 ha), South West Cay (15.2 ha) and South Cay (0.2 ha). ${ }^{145}$ Historical sources indicate that the largest of these, Southwest Cay, is a protected bird sanctuary. ${ }^{146}$ Numerous shelters have been built on the cays by fishers as the area is a productive area for queen conch, and Middle Cay in the same group hosts a Jamaica Defense Force Coast Guard station. ${ }^{147}$ Pedro Cays have been subject to protective legislation since 1907 and are an International Union for Conservation of Nature (IUCN) Category VIII Multiple Use Management Area. ${ }^{148}$ Additionally, high resolution satellite imagery indicates relatively substantial, vegetated above high-tide features (see Figure 2). The southernmost of the Pedro Cays, South Cay, could not be used as an alternative, fall back basepoint in view of its small size, composition and instability. ${ }^{149}$ This illustrates how insular features, especially coral formations, can change relatively swiftly over time. It should be noted here that all of Jamaica's southern features are coral cays.

However, in light of the IPCC projections concerning the persistence of tropical corals in a $1.5{ }^{\circ} \mathrm{C}$ warmer world, the long-term outlook for all of Jamaica's coral cays must be considered to be perilous. ${ }^{150}$ Consequently, were all of Jamaica's southern coral cays, both those located on Pedro Bank and Morant Cays, to be inundated as a result of sea level rise and Jamaica was

\footnotetext{
144 See Hydrographer of the Navy, n. 141 above, p. 25 o.

145 Id., pp. 250-251; UNEP-WCMC, n. 143 above.

146 Hydrographer of the Navy, n. 141 above, p. 25 o.

147 See, for example, N. Zenny, "Pedro Bank Atlantic and Gulf Rapid Reef Assessment (AGRRA), April 18-26, 2005, Summary Report," available online: <https://web.archive.org/ web/20070310204941/http://www.jamaicachm.org.jm/Articles/pedro_Banl.asp >. See also K. Baldwin et al., "Developing Ecosystem-based Information for Marine Spatial Planning on the Pedro Bank, Jamaica," Proceedings of the 67th Gulf and Caribbean Fisheries Institute, 3-7 November 2014, Christ Church, Barbados, available online: $<$ https://www .openchannels.org/literature/12454>.

148 UNEP-WCMC, n. 143 above.

149 South Cay has been reported to be composed of "bleached white coral and shells piled into a bank" with it being noted that the shape and height of this bank "could easily be altered by storm or hurricane." See Hydrographer of the Navy, n. 141 above, p. 251.

15 See IPCC (2018) Global Warming of $1.5^{\circ} \mathrm{C}$, n. 5 above.
} 


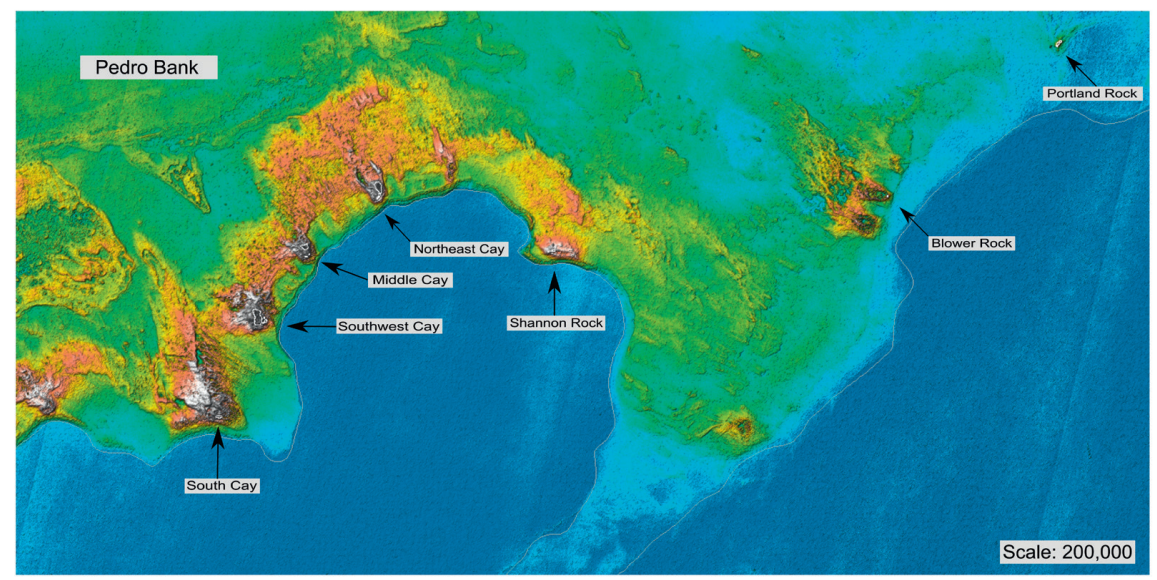

FIgure 2 Pedro Bank

Source: R. Van de Poll. The Fugro 4DSSM analysis of Pedro Banks depicted in Figure 2 depicts all shoaling areas, shallow water information, including smaller drying rocks, drying reefs, sand bars, sand spits and smaller islets and larger cays. This particular image was collected 5 January 2020 , and details $10 \mathrm{~m}$ ground resolution imagery that can show seabed morphology to a maximum of $25.0 \mathrm{~m}$. Although individual scenes appear similar to a bathymetric Digital Terrain Model (DTM) or a Digital Elevation Model (DEM), Fugro 4DSSM is not a bathymetric product. This Fugro 4DSSM source image comes from the European Space Agency (ESA) Copernicus Sentinel-2 satellite (at $10 \mathrm{~m}$ native ground resolution)

forced to, for example, reconfigure its baselines by defining baselines connecting the eastern and western headlands of Jamaica and Portland Rock this would result in a water-to-land ratio of around o.9:1, which would be insufficient for Jamaica to meet the requirements of Article 47 (see Option B on Figure 1). While Jamaica could try to build up and defend threatened features, the inherent costs involved, as illustrated by the admittedly extreme example provided by Okinotorishima, of such an option may well prove to be prohibitively expensive in terms of construction and maintenance of sea defenses and thus probably impractical. ${ }^{151}$

$15^{1}$ Additionally, the construction of sea defenses may also interrupt sediment flow regimes, potentially compromising the capacity of coral islands to naturally adapt to sea level rise. See, for example, P. Kench, "Understanding small island dynamics: A basis to underpin island management," in Proceedings of the International Symposium of Islands and Oceans, 22-23January 2009, ed., H. Terashima (Ocean Policy Research Foundation, 2009), 22-32, pp. 24-28. 
In Grenada, the Porpoise Rocks, which are designated as point 5 in Grenada's archipelagic baselines system are described in the UK Admiralty Pilot of 2012 as "three reefs, and a number of submerged rocks,"152 with the 1969 version of this Pilot recording the heights of the highest points on the eastern and westernmost reefs of the Porpoises as 2 and 3 feet ( 0.6 and $0.9 \mathrm{~m}$ ) in height respectively. ${ }^{153}$ However, the Porpoises are located just off the south coast of the main island of Grenada, so that even without them Grenada would still meet the requirements of Article 47 and not jeopardize its archipelagic status.

Meanwhile, with respect to São Tomé and Príncipe, most of the features anchoring the archipelagic baseline system appear to be rocky and of relatively high elevation and thus unlikely to be vulnerable to inundation by sea level rise. However, Pedra da Galé, designated as Point 8 in São Tomé and Príncipe's archipelagic baseline system, was recorded in the Admiralty Pilot of 1977 as having a height of $2.7 \mathrm{~m}$ or 9 feet, and as being a "small, bare black rock of basaltic formation, on which the sea always breaks." 154 The 2013 version of the same publication includes the same description of the feature but without indicating its height above sea level. ${ }^{155}$ Given the configuration of São Tomé and Príncipe's archipelagic baseline system connecting small islets around two large islands, coupled with a water-to-land ratio of 4.03:1, the loss of this basepoint would not compromise the ability of São Tomé and Príncipe's baselines to meet the requirements of Article 47 of UNCLOS.

An example of the near disappearance of a small feature used in an archipelagic baselines system, albeit as a result of anthropogenic intervention rather than sea level rise, is provided by the Indonesian island of Pulau Nipa (or Nipah). Pulau Nipa is one of many small islands in the Singapore Strait that is not only part of Indonesia's archipelagic baselines system, providing basepoints TR.19o and TR.19oA, but also serves as a key basepoint for the construction of the western extension of the Indonesia-Singapore territorial sea boundary (see Figure 3). ${ }^{156}$ In 2003, it was reported that as a result of extensive

$15^{2}$ United Kingdom Hydrographic Office (U KHO), West Indies Pilot, Volume 2, NP71, 17th ed. (Taunton: UKHO, 2012), p. 109.

153 Hydrographer of the Navy, West Indies Pilot, Volume II, NP71, 11th ed. (Taunton: Hydrographic Department, 1969), p. 122.

154 Hydrographer of the Navy, Africa Pilot, Volume II, NP2, 12th ed. (Taunton: Hydrographic Department, 1977), p. 79.

155 U KHO, Africa Pilot, Volume 3, NP17, 17th ed. (Taunton: UKHO, 2013), p. 107.

156 See C.H. Schofield, T.L. McDorman and I.M.A. Arsana, "Treaty between the Republic of Indonesia and the Republic of Singapore relating to the delimitation of the Territorial Seas of the Two Countries in the Eastern Part of the Strait of Singapore," in The International Maritime Boundaries, Vol. viI, ed., C. Lathrop (Leiden/Boston: American Society for International Law (ASIL)/Martinus Nijhoff, 2016), pp. 4,813-4,824; Badan Informasi 


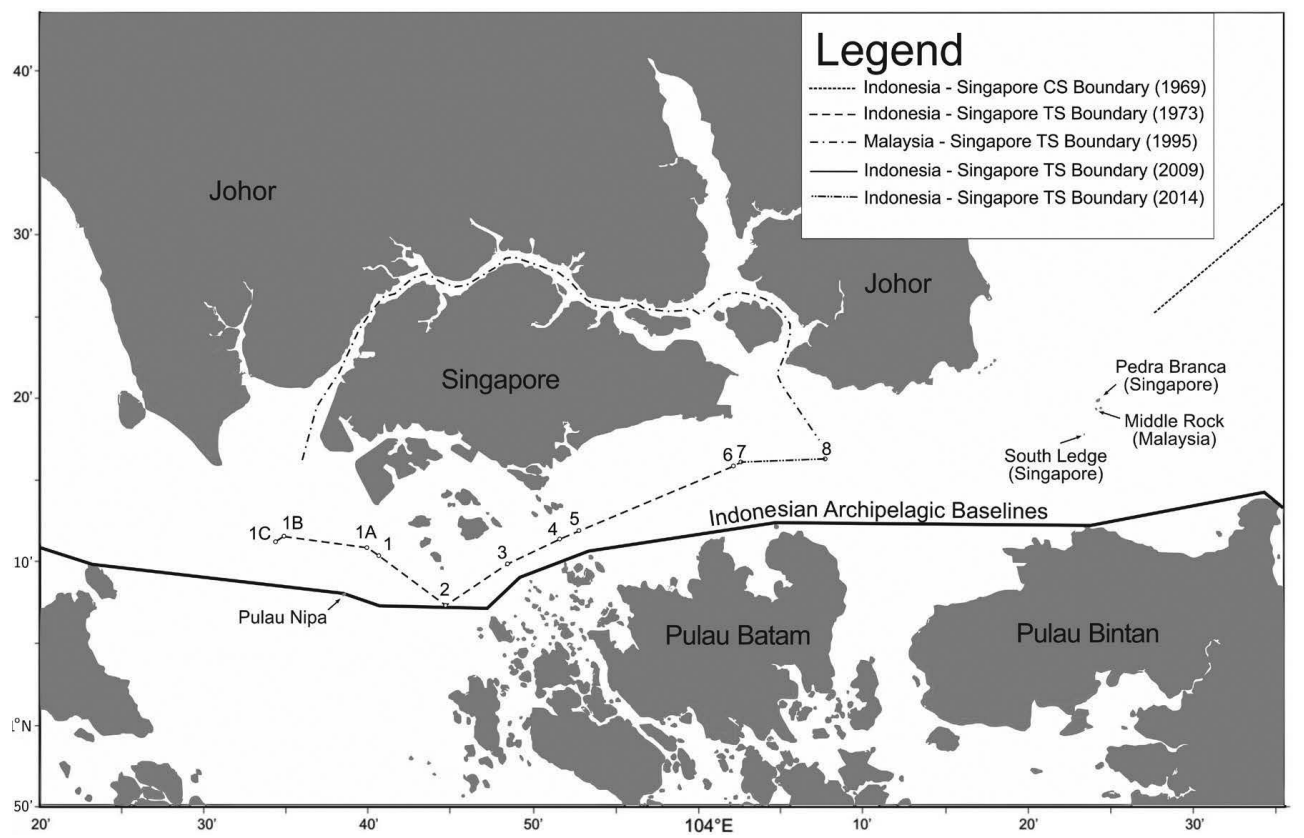

FIGURE 3 Baselines and maritime boundaries in the Singapore Strait SOURCE: THE AUTHORS

sand-mining activities, the island had reportedly been reduced to less than one hectare in area and was in danger of becoming entirely submerged. ${ }^{157}$ Indonesia responded by undertaking extensive reclamation works resulting in Pulau Nipa being elevated well above sea level and expanded to around 60 hectares in area. ${ }^{158}$

Geospasial [Agency for Geospatial Information] (BIG), Peta Negara Kesatuan Republik Indonesia [Map of the Unitary State of the Republic of Indonesia], (Cibinong, 2017).

157 Approximately 300 million cubic meters of sand was reportedly being dredged from the vicinity of the island on an annual basis and largely exported to Singapore. See C. Milton, "The Sand Smugglers," Foreign Policy (4 August 2010), available online: <https://foreign policy.com/2010/08/04/the-sand-smugglers/>.

158 In 2004, Indonesian President Megawati Soekarnoputri visited Pulau Nipa and unveiled a plaque designed to reaffirm Indonesia's claim to sovereignty over the feature bearing the inscription "Defend it till the last drop of your blood." See "Megawati Signs Plaque in Nipah Island," Antara (20 February 2004). Indonesia instituted a ban on sand exports in 2007, although illegal sand mining and smuggling reportedly remains a problem. In the 2009 Boundary Treaty, Indonesia succeeded in securing the use of the archipelagic baseline between Pulau Nipa and Pulau Karimun Kecil (TR.189) to the west for the delimitation of the extension of the Indonesia-Singapore territorial sea boundary. See Schofield, McDorman and Arsana, n. 156 above, p. 4,817. 
In the context of the current discussion it is perhaps useful to consider the situation where an island used as a basepoint in an archipelagic baseline system is completely submerged and then rebuilt. The question arises as to whether the rebuilt feature is entitled to be treated as an island for the purposes of defining archipelagic baselines. In line with the approach taken in the South China Sea award-where the tribunal spent a great deal of effort examining the original "natural" status of the disputed features-it can be suggested that where a feature that qualifies as a natural island disappears and is then artificially rebuilt, it might resume its original island status.

\section{Reefs}

The overwhelming majority of States that claim archipelagic status are in warm tropical waters, where the reef building corals are a major feature of coastal ecosystems. So it is no surprise that many archipelagic States have included basepoints located on reefs in their archipelagic baselines systems. ${ }^{159}$ In fact, a number of archipelagic States are entirely or predominantly composed of low elevation coral atolls and related reef islands. Notable examples include the Marshall Islands, Kiribati and Tokelau in the Pacific Ocean and the Maldives in the Indian Ocean. ${ }^{160}$ The key consideration in relation to sea level rise impacts on coral reef features is the interaction, including complex feedbacks, between rising sea levels and the coastal ecosystems in question. In particular, corals have the ability to respond to changing sea levels and both gain elevation and provide sediments that enable island-building processes to occur. There is clear evidence that coral reefs and islands can be remarkably robust and enduring features, capable of natural adaptation to sea level rise over time, with the geological record indicating that atolls have survived sea levels half a meter higher than present levels. ${ }^{161}$

159 See the very careful analysis of the role of reefs in P.B. Beazley, "Reefs and the 1982 Convention on the Law of the Sea," International Journal of Estuarine and Coastal Law 6 (1991): 281-312.

16o Kiribati consists of 32 atolls and reef island features together with one raised island feature, Banaba (Ocean) Island. Tokelau is a self-administering territory of New Zealand. Here it can be noted that Article 6 of unCLOs refers to "islands situated on atolls" or "islands having fringing reefs" meaning that for this provision to apply, islands must be present.

161 See Kench, n. 151 above. See also A.P. Webb, "Coastal vulnerability and monitoring in the Central Pacific Atolls," in Terashima, n. 151 above, pp. 33-38. Webb indicates that there exist examples of net-island growth which runs counter to "established thought, non-scientific reports in the popular media and modelling" and are suggestive of the complexity of shoreline responses to sea level rise (Id., p. 37). 
In the context of a changing global ocean, the issue is whether the natural processes that allow coral reef islands to adapt to changing sea levels can be maintained in the face of significantly accelerated sea level rise. This is especially against the backdrop of warming, ${ }^{162}$ acidification and deoxygenation of the ocean which, moreover, include increasingly frequent extreme weather events such as intense storms. ${ }^{163}$ All of these factors are likely to seriously impair the ability of coral reefs to respond to rising sea levels and thus impair the resilience of coral reef islands. 164

A recent study suggested that only nine percent of coral reefs are likely to be able to "keep up" with the IPCC current, and arguably overly conservative, projected rates of sea level rise. ${ }^{165}$ Such studies raise concerns that previously stable coral reef shorelines may become more erosive in character and thus less able to provide protection to reef islands as well as offer the sediment necessary to support island building processes on and within reef systems. The consequences of this may be the erosion and disappearance of entire islands or, at the least, significant changes to island shoreline stability, leading to reduced island habitability.

162 The potentially disastrous effects of ocean warming for coral reefs are underscored by the increasing frequency and severity of coral reef bleaching events. See, for example, P.P. Wong et al., "Coastal systems and low-lying areas," in Climate Change 2014: Impacts, Adaptation, and Vulnerability. Part A: Global and Sectoral Aspects. Contribution of Working Group II to the Fifth Assessment Report of the Intergovernmental Panel on Climate Change, eds., C.B. Field et al. (Cambridge, UK: Cambridge University Press, 2014), 361-409, p. 378. See also T.P. Hughes et al., "Global warming and recurrent mass bleaching of corals," Nature 543 (2017): 373-377; T.P. Hughes, K.D. Anderson and S.R. Connolly, "Spatial and temporal patterns of mass bleaching in the Anthropocene," Science 359 (2018): 80-83; R. van Hooidonk et al., "Local-scale projections of coral reef futures and implications of the Paris Agreement," Scientific Reports 6 (39666) (2016): 1-8; T.L. Frölicher, E.M. Fischer and N. Gruber, "Marine heatwaves under global warming," Nature 56o (2018): 36o-364; T.P. Hughes et al., "Global warming transforms coral reef assemblages," Nature 556 (2018): $492-496$.

163 Such events can be highly destructive for coastal ecosystems such as corals and, coupled with multiple other factors such as disease, food web changes, invasive organisms and heat stress mortality, may "overwhelm the capacity for natural and human systems to recover following disturbances." See IPCC $1.5{ }^{\circ} \mathrm{C}$ Special Report, n. 5 above, p. 223.

164 The absorption of carbon dioxide by the ocean leads to ocean waters becoming more acidic which, in turn, impairs the ability of calcifying organisms such as corals to form, leading to reduced levels of calcification and enhanced skeletal dissolution and coral mortality.

165 See C.T. Perry et al., "Loss of coral reef growth capacity to track future increases in sea level," Nature 558 (2018): 396-40o. See also S. Albert et al., "Interactions between sea-level rise and wave exposure on reef island dynamics in the Solomon Islands," Environmental Research Letters 11 (2016): 1-9, p. 1. 
Indeed, the 2018 IPCC Special Report on Global Warming of $1.5^{\circ} \mathrm{C}$ provides a stark warning concerning the future for tropical corals even if warming is restrained to $1.5^{\circ} \mathrm{C}$. The Special Report rightly numbers tropical corals among the critically important "framework organisms" or "ecosystem engineers" that build structures providing the habitat for large numbers of species. ${ }^{166}$ However, the report assesses present-day risks to reef-building tropical corals as "high" with "evidence of strengthening concern" since the release of IPCC AR5 that tropical corals "may be even more vulnerable to climate change" than indicated in assessments conducted in 2014. ${ }^{167}$ Consequently, the IPCC 2018 Special Report on Global Warming of $1.5{ }^{\circ} \mathrm{C}^{168}$ suggested that even if warming were to be restrained to $1.5^{\circ} \mathrm{C}$ above pre-industrial levels, the result would be a "further loss of $90 \%$ of reef-building corals compared to today,"169 and that if warming reached $2{ }^{\circ} \mathrm{C}$ above pre-industrial levels, coral losses were estimated at a calamitous 99 percent. ${ }^{170}$

Archipelagic States using reefs as key parts of their baselines system include the Bahamas, Comoros, Fiji, Indonesia, Kiribati, Maldives, Marshall Islands, Mauritius (Chagos archipelago), ${ }^{171}$ Papua New Guinea, the Philippines, Seychelles, Solomon Islands and Tuvalu. The IPCC projections regarding the future fate of the tropical corals, which may be quite conservative, suggest that a number of these archipelagic claims may be under existential threat. As noted above, States wholly or predominantly composed of coral features would appear to be most at risk.

\section{Low-tide Elevations}

Baumert and Melchior looked at the use of LTEs as archipelagic basepoints and commented that " $[\mathrm{m}]$ ost states have drawn their archipelagic baselines using only islands and, therefore, have not implicated paragraph 4."172 They suggest

\footnotetext{
166 IPCC $1.5{ }^{\circ} \mathrm{C}$ Special Report, n. 5 above, p. 84.

167 Id.

168 Id.

169 Id., Chapter 3, p. 84.

170 Id.

171 Concerning the archipelagic claims of Mauritius, it can be noted that these include the Chagos Archipelago which the United Kingdom considers to constitute the British Indian Ocean Territory. Accordingly, the United Kingdom duly protested the archipelagic claims of Mauritius. See Roach and Smith, n. 92 above, p. 210. The United Kingdom has maintained its sovereignty claims concerning the Chagos Archipelago despite the Advisory Opinion of the International Court of Justice in Legal Consequences of the Separation of the Chagos Archipelago from Mauritius in 1965, ICJ Reports 2019, p. 95.

172 Baumert and Melchior, $n .138$ above. This is still the case when the three more recent archipelagic claims of Saint Vincent and the Grenadines, the Marshall Islands and Kiribati are
} 
that only two States may have utilized LTEs: the Dominican Republic and Trinidad and Tobago. ${ }^{173}$ Additionally, they point out that Comoros appears to use a submerged basepoint and that Seychelles has utilized anomalous "open water" floating basepoints. ${ }^{174}$ Although the latter two types of basepoints are not threatened by sea level rise they are included in the following section as examples of problematic State practice in selecting archipelagic basepoints.

\section{The Dominican Republic}

The use of LTES in archipelagic baselines is a point of dispute between the Turks and Caicos and the Dominican Republic. In 1996, the United Kingdom (on behalf of the Turks and Caicos Islands) and the Dominican Republic concluded a maritime boundary agreement, seemingly calculated on the basis of a median line measured from the normal baselines of both signatories. ${ }^{175}$ The boundary line connects five terminal or turning points with four straight line segments stretching for $283 \mathrm{M}$ overall with Mouchoir Bank located on the northern (Turks and Caicos) side of the line and Silver and Navidad Banks being located on the southern (Dominican Republic) side of the line (see Figure 4) ${ }^{176}$ The delimitation of this all-purpose maritime boundary between the parties should have settled matters. ${ }^{177}$ The agreement is not, however, in force.

included. See U.S. Department of State, "Saint Vincent and the Grenadines: Archipelagic and Other Maritime Claims and Boundaries," Limits in the Seas, No. 144 (Washington, DC: Office of Ocean and Polar Affairs, Bureau of Oceans and International Environmental and Scientific Affairs, 28 October 2019); U.S. Department of State, "Republic of The Marshall Islands: Archipelagic and Other Maritime Claims And Boundaries," Limits In The Seas, No. 145 (Washington, DC: Office of Ocean and Polar Affairs, Bureau of Oceans and International Environmental and Scientific Affairs, 14 February 2020); U.S. Department of State, "Republic of Kiribati Archipelagic and Other Maritime Claims and Boundaries," Limits in the Seas, No. 146 (Washington, DC: 5 March 2020); and, Pers. Comm., Kevin Baumert, 23 August 2020.

173 Baumert and Melchior, n. 138 above, p. 66.

174 Id.

175 Agreement between the Government of the United Kingdom of Great Britain and Northern Ireland and the Government of the Dominican Republic Concerning the Delimitation of the Maritime Boundary between the Dominican Republic and the Turks and Caicos Islands, 2 August 1996, not in force. See J.I. Charney and L.M. Alexander, eds., International Maritime Boundaries, Vol. III (Dordrecht: Martinus Nijhoff, 1998), pp. $2,235^{-2,243 .}$

176 Id., Vol. I, p. 235.

177 The preamble to the agreement states its purpose as being "to delimit the maritime areas between the Dominican Republic and the Turks and Caicos Islands in accordance with the principles of international law." See Charney and Alexander, n. 175 above, pp. 2,237 and 2,242 . 


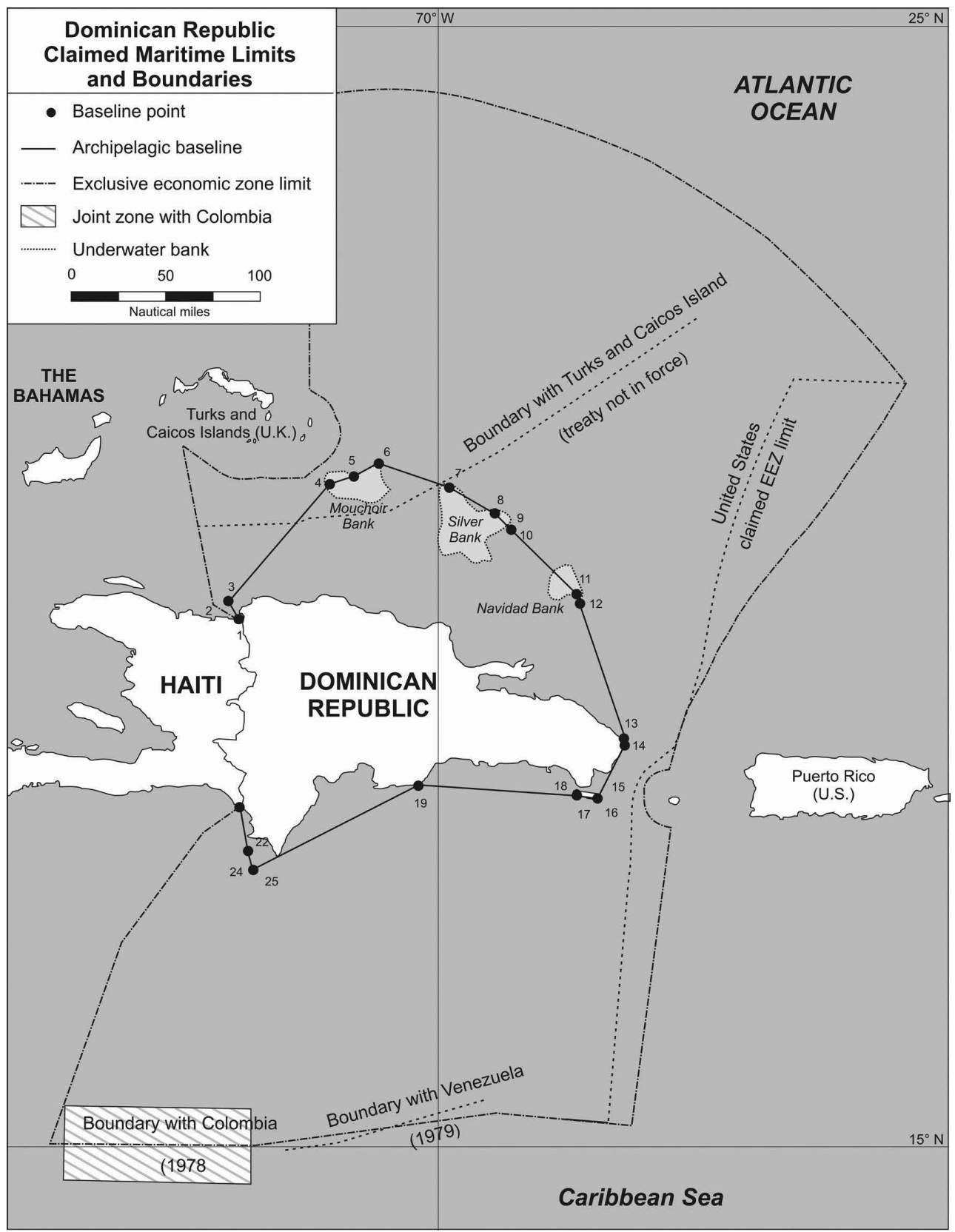

FIGURE 4 Archipelagic baselines, maritime claims and boundaries between the Dominican Republic and the Turks and Caicos Islands

SOURCE: C.H. SCHOFIELD AND R.N. SCHOFIELD, "TESTING THE WATERS: CHARTING THE EVOLUTION OF CLAIMS TO AND FROM LOW-TIDE ELEVATIONS AND ARTIFICIAL ISLANDS UNDER THE LAW OF THE SEA," ASIA-PACIFIC JOURNAL FOR OCEAN LAW AND POLICY 1 (2016): 37-67, P. 56 
Subsequently, in 2007, the Dominican Republic passed legislation regarding its maritime claims, including a system of archipelagic baselines. ${ }^{178}$ As Baumert and Melchior note, the Dominican Republic's archipelagic baselines claims include eight baseline segments that "appear to be drawn from points in LTES." ${ }^{179}$ As these LTEs are all located beyond the territorial sea of the nearest island, these features are therefore not appropriate for hosting archipelagic basepoints, that is, "unless lighthouses or similar installations which are permanently above sea have been built on them," in keeping with Article 47(4) of UNCLOS. However, none of these LTEs have lighthouses or other installations on them.

In addition, the Dominican Republic opted to define archipelagic basepoints on features, including Mouchoir Bank which, as noted above, is located on the Turks and Caicos rather than the Dominican Republic's side of the maritime boundary line agreed in 1996. This claim on the part of the Dominican Republic therefore appears to contravene that agreement though, as pointed out above, it is not yet in force (see Figure 4). The explanation for this claim is that it is only through the use of these outlying banks that the Dominican Republic can overcome the requirement that its archipelagic baselines enclose as much water as land in accordance with Article 47(1) of UNCLOS and therefore qualify as an archipelagic State. In a joint demarche of October 2007, the United Kingdom and the United States protested the Dominican Republic's claims and requested further information. ${ }^{180}$

\section{Trinidad and Tobago}

In its archipelagic baselines system Trinidad and Tobago utilizes an LTE which is within $12 \mathrm{M}$ of the nearest island (as permitted by Article 47(4)). Sea level change could eventually mean that this feature becomes a fully submerged one and thus invalid as a basepoint, thus necessitating a revision of Trinidad and Tobago's archipelagic baselines system. The loss of this basepoint would not, however, threaten the validity of these baselines.

178 Dominican Republic Law No. 66-07, 22 May 2007 (in effect 22 May 2007). See U.S. Department of State, "Dominican Republic: Archipelagic and other Maritime Claims and Boundaries," Limits in the Seas, No. 130 (Washington, DC: Office of Ocean and Polar Affairs, Bureau of Oceans and International Environmental and Scientific Affairs, 31 January 2014), pp. 9-12 [hereinafter Dominican Republic Archipelagic Claims].

179 Baumert and Melchior, n. 138 above, p. 66. See also S. Kopela, "2007 archipelagic legislation of the Dominican Republic: An assessment," International Journal of Marine and Coastal Law 24 (2009): 501-533; S. Kopela, Dependent Archipelagos in the Law of the Sea (Boston: Martinus Nijhoff Publishers/Brill Academic, Publications on Ocean Development, vol. 74, 2013).

180 Dominican Republic Archipelagic Claims," n. 178 above, pp. 15-16. 


\section{Comoros}

The Comoros archipelagic baseline claim includes a basepoint located above Banc Vailheu, which according to the relevant Admiralty Pilot is an entirely and permanently submerged bank with a reported least depth of water over it of $4.9 \mathrm{~m} .{ }^{181}$ The Comoros also defines baselines around a disputed feature (Mayotte). ${ }^{182}$ However, even excluding those features, Comoros could still meet the Article 47 requirements.

\section{Seychelles}

It has also been observed that the archipelagic baseline system of Seychelles appears to use a number of controversial "open water" basepoints, but if it were to discount them and simply draw a straight baseline, that straight line would be less than $100 \mathrm{M}$ long and permitted by Article $47(2) \cdot{ }^{183}$ It can be observed, however, that the archipelagic baseline claims of Seychelles can still be considered problematic because, according to the U.S. Department of State analysis, only one of the four distinct systems of archipelagic baselines defined by Seychelles meets the water-to-land ratio and collectively they also do not meet this test. ${ }^{184}$

This brief review suggests that the actual use of LTEs themselves as basepoints is not widespread. What is more difficult to assess is the extent to which a one or two meter sea level rise would render some of the existing insular features de facto LTEs.

181 UKHO, South Indian Ocean Pilot, NP39, 14th ed. (Taunton: UKHO, 2014), p. 58.

182 In 1974, when the Comoro Islands was on the verge of independence from France, the population of one of the islands making up the Comoros archipelago, Mayotte, instead voted in favor of remaining under French jurisdiction. While the Comoros could construct a system of archipelagic baselines compliant with UNCLOS, it maintains a claim to sovereignty over Mayotte and accordingly includes Mayotte within its baselines claim. Unsurprisingly, France has protested the inclusion of Mayotte in the Comoros Islands archipelagic claim. See, for example, U.S. Department of State, "Comoros: Archipelagic and other Maritime Claims and Boundaries," Limits in the Seas, No. 134 (Washington, DC: Office of Ocean and Polar Affairs, Bureau of Oceans and International Environmental and Scientific Affairs, 28 March 2014), p. 3 .

183 Notably, baseline points 7-9, 11-13, 23-24, 29-33, 42, and 45 (Group 1), 46-48, 63-69, 77-79, and 89-93 (Group 2), 103-106 and 119-121 (Group 3), and points 124-125 and 134137 (Group 4). See Seychelles Archipelagic Claims," n. 132 above, p. 4.

184 The four groups have water-to-land ratios of 10.58:1, 239.93:1, 44.5:1 and 5.15:1 respectively. Overall the ratio of water to land for Seychelles is almost 17:1. See Id., pp. 2-3. As noted above, however, Seychelles has calculated contrasting water-to-land ratios of 8.972:1, 4.94:1, 2.37:1, and 1.58:1. See n. 134 above. 


\section{Conclusion}

From this preliminary assessment of the impacts of sea level rise on archipelagic baselines it is possible to draft a few equally preliminary conclusions as to risks arising. In particular, it is possible to highlight some of the archipelagic baseline points most at risk. Clearly, low-tide elevation basepoints, which are permitted if they are "a distance not exceeding the breadth of the territorial sea from the nearest island," 185 are the most at risk from sea level rise. Low-tide elevations are, however, not widely used as basepoints in archipelagic baseline systems.

Also at high risk are coral reef basepoints. As discussed above, the IPCC has raised significant doubts over whether coral reef structures employed as basepoints for archipelagic baseline claims can continue growing and keep up with sea level rise, especially in the context of an increasingly warm, acidic and deoxygenating ocean. This could have major implications for archipelagic baseline systems involving reefs. For example, as demonstrated above, the loss of low elevation coral features such as Jamaica's southern cays would have major impacts and put the Jamaican archipelagic status at serious risk.

Second, this survey reveals some of the unequal impacts that result from the essentially political compromises that were made by the negotiators at UNCLOS III as part of the UNCLOS package deal, and that are reflected in the requirements for archipelagic status set out in Articles 46 and 47 of UNCLOS. As indicated, key decisions were made in closed session by only four island States with the major maritime States, which were primarily concerned with preserving their existing rights in relation to navigation, and the laying of submarine pipelines and cables. Once the basic archipelagic concept had been agreed, then the determination of the length of the longest baselines and the ratio of water to land were reportedly developed to accommodate the geographical requirements of the States that were at that point considering themselves eligible to claim that status. At the end of the Conference the following announced their intent to claim this status: Bahamas, Cape Verde, Fiji, the Netherlands Antilles, Papua New Guinea, the Philippines and the Solomon Islands. ${ }^{186}$

Omitted from that list were at least five developing island countries which had only just achieved independence (Antigua and Barbuda (1981), St. Vincent

185 UNCLOS, n. 3 above, Article 47(4).

186 Virginia Commentary, n. 80 above, Vol. II, p. 403. This reports that São Tomé and Príncipe made a declaration on signing the Convention in 1982 that the provisions "were compatible as regards its sovereignty and jurisdiction over its maritime space?" Id. 
and the Grenadines (1980)), or had not yet achieved it (Kiribati, Marshall Islands and Tuvalu). These last three-small predominantly coral atoll and reef-based islands in the Pacific - have undoubtedly benefitted enormously from their ability to claim broad maritime entitlements and the rich pelagic fishery resources that accompany them. ${ }^{187}$ However, these three States are also at the frontline in terms of the likely impacts of sea level rise and it may become increasingly difficult for them to maintain those entitlements if baselines are indeed ambulatory and they lose key islands and reefs and thus potentially turning points in their archipelagic baseline systems, which make them unable to meet the requirements of Article 47. This makes them particularly vulnerable.

Foremost among the technical problems is the water-to-land ratio discussed above. In fact, Article 47(1) specifically permits baselines to be drawn joining the outermost points of the outermost islands and drying reefs of an archipelago (not the archipelagic State) "provided that within such baselines are included the main islands and an area in which the ratio of the area of the water to the area of the land, including atolls, is between 1 to 1 and 9 to 1 " (emphasis added).

As indicated above, a plain reading of the Article $47(1)$ provision is indeed that both requirements are necessary for each archipelago. However, because of the unusual way the methodology was agreed upon, there seems to be little record of the discussions at UNCLOS III which led to the requirement that each archipelago meet this criterion. ${ }^{188}$

The next general observation stems from the ratio discussion and relates generally to the resilience of the archipelagic regime developed by UNCLOS to the impacts of sea level rise. This article is a preliminary risk assessment, it is not intended to be a comprehensive review of national compliance with Part IV. However, based on the considerations discussed above, it is worth pointing out that every single one of the twenty-two States that have claimed archipelagic status set out in Appendix II have utilized the quite legitimate but high risk features of low-lying islands, coral reef features or low-tide elevations as archipelagic basepoints. Loss of those features would not necessarily mean that these States would be unable to meet the baseline requirements of Article 47

187 These States would, in any event, have been able to claim very large E Ezs from their island baselines, but archipelagic baselines serve both to enhance and to an extent stabilize their maritime entitlements. See, for example, Marshall Islands in Freestone and Schofield, n. 31 above.

188 The U.S. State Department has consistently highlighted individual archipelagos that do not meet the 9:1 ratios as not being "in conformance with international law." See, for example, U.S. Department of State, n. 178 above, p. 4. 
so that their ability to maintain their archipelagic status is compromised, but it clearly would for a number of States already discussed. Moreover, nearly a third of the twenty-two archipelagic States already appear to have problems associated with drawing basepoints. This is, of course, before the sea level rise predictions by IPCC are factored in.

It can also be observed that, somewhat counterintuitively, for a desktop study of this kind concerned in particular with the elevation of features, older sources of hydrographic information can prove to be of more utility than more modern ones. This stems from the transition from paper to electronic charting of hydrographic data. While the latter is certainly more positionally accurate, such sources tend not to record the heights above sea level of insular features used as archipelagic basepoints. As noted earlier, the Arbitral Tribunal in the South China Sea Case commented similarly, "[a]s with published nautical charts, satellite navigation has also caused the more-recent editions of the pilots to become less descriptive of the features on reefs and correspondingly less useful" for the assessment of insular features. ${ }^{189}$

Finally, and on a positive note, it can be observed that these risks to the archipelagic status, baselines and maritime claims of archipelagic States can be tackled through a progressive interpretation of the international law of the sea. In particular, if the international community were to accept the recommendation made by the ILA in 2018, and voiced by the South Pacific Forum Leaders in Tuvalu in 2019, that baselines and maritime zone claims that have been established in accordance with provisions of UNCLOS should be regarded as being "sea level rise proof," then the claims of archipelagic States would be protected once defined and declared in communications to the United Nations Secretary-General. ${ }^{190}$

This approach was strongly advocated in November 2019 by the representative of Papua New Guinea who intervened in the debate at the UN Sixth (Legal) Committee. He referred positively to the work of the ILA and commented that:

[I]n order to foster legal certainty and stability, facilitate orderly relations between States and avoid conflict, affected States should be able to maintain existing entitlements to maritime zones in accordance with the United Nations Concretion on the Law of the Sea. They should also be able to maintain their maritime boundaries as delimited by

189 See South China Sea Arbitration, n. 56 above, para. 332.

190 However, this does suggest that those archipelagic claims that are not established in accordance with the provisions of UNCLOS might necessarily remain at risk. 
agreement between States or by decisions of international courts or arbitral tribunals. ${ }^{191}$

This present study is a preliminary risk analysis of the impact of sea level rise resulting from anthropogenic climate changes. However, it is already clear that, as a group, archipelagic States appear to be highly likely to be impacted by these predicted rises unless steps are taken legally to recognize the stability of their baselines and thus secure their maritime entitlements.

\section{Appendix I}

\section{PART IV}

\section{ARCHIPELAGIC STATES}

\section{Article 46}

\section{Use of terms}

For the purposes of this Convention:

(a) "archipelagic State" means a State constituted wholly by one or more archipelagos and may include other islands;

(b) "archipelago" means a group of islands, including parts of islands, interconnecting waters and other natural features which are so closely interrelated that such islands, waters and other natural features form an intrinsic geographical, economic and political entity, or which historically have been regarded as such.

191 Mr. Sarufa (Papua New Guinea), UNGA, Sixth Committee, Summary record of the 3oth meeting, 5 November 2019, UN Doc. A/C.6/74/SR.30 (5 November 2019), paras. 18-20. 


\section{Article 47}

\section{Archipelagic baselines}

1. An archipelagic State may draw straight archipelagic baselines joining the outermost points of the outermost islands and drying reefs of the archipelago provided that within such baselines are included the main islands and an area in which the ratio of the area of the water to the area of the land, including atolls, is between 1 to 1 and 9 to 1 .

2. The length of such baselines shall not exceed 100 nautical miles, except that up to 3 per cent of the total number of baselines enclosing any archipelago may exceed that length, up to a maximum length of 125 nautical miles.

3. The drawing of such baselines shall not depart to any appreciable extent from the general configuration of the archipelago.

4. Such baselines shall not be drawn to and from low-tide elevations, unless lighthouses or similar installations which are permanently above sea level have been built on them or where a low-tide elevation is situated wholly or partly at a distance not exceeding the breadth of the territorial sea from the nearest island.

5. The system of such baselines shall not be applied by an archipelagic State in such a manner as to cut off from the high seas or the exclusive economic zone the territorial sea of another State.

6. If a part of the archipelagic waters of an archipelagic State lies between two parts of an immediately adjacent neighbouring State, existing rights and all other legitimate interests which the latter State has traditionally exercised in such waters and all rights stipulated by agreement between those States shall continue and be respected.

7. For the purpose of computing the ratio of water to land under paragraph $\mathrm{l}$, land areas may include waters lying within the fringing reefs of islands and atolls, including that part of a steep-sided oceanic plateau which is enclosed or nearly enclosed by a chain of limestone islands and drying reefs lying on the perimeter of the plateau.

8. The baselines drawn in accordance with this article shall be shown on charts of a scale or scales adequate for ascertaining their position. Alternatively, lists of geographical coordinates of points, specifying the geodetic datum, may be substituted.

9. The archipelagic State shall give due publicity to such charts or lists of geographical coordinates and shall deposit a copy of each such chart or list with the Secretary-General of the United Nations. 


\section{Appendix II}

Use of vulnerable basepoints in systems of archipelagic baselines

\begin{tabular}{|c|c|c|c|c|}
\hline $\begin{array}{l}\text { State } \\
\text { (Year joined UN) }\end{array}$ & $\begin{array}{l}\text { Low-lying } \\
\text { islands }\end{array}$ & Reefs & LTES & $\begin{array}{l}\text { Water-to-land } \\
\text { ratio }^{\mathrm{a}}\end{array}$ \\
\hline Antigua and Barbuda (1981) & & $\checkmark$ & & 7.19:1 \\
\hline The Bahamas (1973) & & $\checkmark$ & & $6.86: 1$ \\
\hline Cape Verde (1975) & $\checkmark$ & & & 8.92:1 \\
\hline Comoros (1975) & $\checkmark$ & $\checkmark$ & & 6.99:1 \\
\hline Dominican Republic (1945) & & & $\checkmark$ & 1.03:1 \\
\hline Fiji (1970) & & $\checkmark$ & & $2.98: 1$ \\
\hline Grenada (1974) & $\checkmark$ & & & $1.61: 1$ \\
\hline Indonesia (1950) & & & $\checkmark$ & 1.61:1 \\
\hline Jamaica (1962) & $\checkmark$ & & & $2.0: 1$ \\
\hline Kiribati (1999) & & $\checkmark$ & & $\begin{array}{l}\text { x2 systems: } \\
\text { 1. } 8.72: 1 \\
\text { 2. } 8.47: 1 \\
\text { Collectively: } \\
8.62: 1\end{array}$ \\
\hline Maldives (1965) & & $\checkmark$ & & $2.63: 1$ \\
\hline The Marshall Islands (1991) & & $\checkmark$ & & $\begin{array}{l}\text { x2 systems: } \\
\text { 1. } 8.54: 1 \\
\text { 2. } 9 \cdot 56: 1 \\
\text { Collectively: } \\
8.97: 1\end{array}$ \\
\hline Mauritius (1968) & & $\checkmark$ & & $\begin{array}{l}\text { x2 systems: } \\
\text { 1. } 2.84: 1 \\
\text { 2. } 7 \cdot 5: 1 \\
\text { Collectively: } \\
6.41: 1\end{array}$ \\
\hline Papua New Guinea (1975) & & $\checkmark$ & & $1.22: 1$ \\
\hline The Philippines (1945) & & $\checkmark$ & & 1.98:1 \\
\hline São Tomé and Príncipe (1975) & $\checkmark$ & & & 4.03:1 \\
\hline
\end{tabular}

a These ratios are drawn from the U.S. Limits in the Seas publications. See Baumert and Melchior, n. 138 above. Additionally, those for Kiribati and the Marshall Islands are derived from U.S. Department of State, n. 172 above. 
(cont.)

\begin{tabular}{lllll}
\hline State & Low-lying & Reefs & LTEs & $\begin{array}{l}\text { Water-to-land } \\
\text { ratio }\end{array}$ \\
(Year joined UN) & islands & & & rats
\end{tabular}

Seychelles $(1976)^{b}$

X4 systems:

1. 10.58:1

2. 239.93:1

3. $44.5: 1$

4. 5.15:1

Collectively:

The Solomon Islands (1978)

17:1

X5 systems:

1. 4.06:1

2. $4.44: 1$

3. $0.29: 1^{\mathrm{c}}$

4. $7.03: 1$

5. 3.57:1

Collectively:

Saint Vincent and the

$4 \cdot 31: 1^{\mathrm{d}}$

$3.81: 1$

Grenadines (1980)

Trinidad and Tobago (1962)

1.39:1

Tuvalu (2000)

7.58:1

Vanuatu (1981)

5.83:1

b As noted above, Seychelles' own ratio calculations for the four groups are as follows: 8.972:1 (Group 1), 4.94:1 (Group 2), 2.37:1 (Group 3), and 1.58:1 (Group 4). See n. 134.

c If the atoll lagoon waters of the Ontong Java group archipelago are considered as part of land area; the water-to-land ratio is 29.92:1 if atoll areas are counted as part of water area. See Solomon Islands Archipelagic Claims, above n. 127, p. 3.

d If the atoll waters of the Ontong Java group archipelago are considered as part of land area. The overall water-to-land ratio is 4.31:1 if atoll lagoon areas are counted as part of water area. Id. 